Article

\title{
Tricyclic Nucleobase Analogs and Their Ribosides as Substrates and Inhibitors of Purine-Nucleoside Phosphorylases III. Aminopurine Derivatives
}

\author{
Alicja Stachelska-Wierzchowska ${ }^{1, *(\mathbb{D}}$, Jacek Wierzchowski $\left.{ }^{1}{ }^{(}\right)$, Michał Górka ${ }^{2,3}$ (), \\ Agnieszka Bzowska $^{2}$ (D), Ryszard Stolarski ${ }^{2}\left(\mathbb{D}\right.$ and Beata Wielgus-Kutrowska ${ }^{2, *}$ \\ 1 Department of Physics and Biophysics, University of Warmia and Mazury in Olsztyn, 10-719 Olsztyn, \\ Poland; jacek.wie@uwm.edu.pl \\ 2 Division of Biophysics, Institute of Experimental Physics, Faculty of Physics, University of Warsaw, \\ 5 Pasteura St., 02-093 Warsaw, Poland; michal.gorka@fuw.edu.pl (M.G.); \\ Agnieszka.Bzowska@fuw.edu.pl (A.B.); Ryszard.Stolarski@fuw.edu.pl (R.S.) \\ 3 Biological and Chemical Research Centre, University of Warsaw, 101 Zwirki i Wigury St., \\ 02-089 Warsaw, Poland \\ * Correspondence: alicja.stachelska@uwm.edu.pl (A.S.-W.); Beata.Wielgus-Kutrowska@fuw.edu.pl (B.W.-K.); \\ Tel.: +48-895-233-406 (A.S.-W.); Fax: +48-895-233-861 (A.S.-W)
}

Academic Editor: Derek J. McPhee

Received: 5 December 2019; Accepted: 30 January 2020; Published: 5 February 2020

\begin{abstract}
Etheno-derivatives of 2-aminopurine, 2-aminopurine riboside, and 7-deazaadenosine (tubercidine) were prepared and purified using standard methods. 2-Aminopurine reacted with aqueous chloroacetaldehyde to give two products, both exhibiting substrate activity towards bacterial (E. coli) purine-nucleoside phosphorylase (PNP) in the reverse (synthetic) pathway. The major product of the chemical synthesis, identified as $1, \mathrm{~N}^{2}$-etheno-2-aminopurine, reacted slowly, while the second, minor, but highly fluorescent product, reacted rapidly. NMR analysis allowed identification of the minor product as $\mathrm{N}^{2}, 3$-etheno-2-aminopurine, and its ribosylation product as $\mathrm{N}^{2}, 3$-etheno-2-aminopurine- $\mathrm{N}^{2}-\beta$-D-riboside. Ribosylation of $1, \mathrm{~N}^{2}$-etheno-2-aminopurine led to analogous $\mathrm{N}^{2}-\beta$-D-riboside of this base. Both enzymatically produced ribosides were readily phosphorolysed by bacterial PNP to the respective bases. The reaction of 2 -aminopurine- $\mathrm{N}^{9}-\beta$ -D-riboside with chloroacetaldehyde gave one major product, clearly distinct from that obtained from the enzymatic synthesis, which was not a substrate for PNP. A tri-cyclic 7-deazaadenosine (tubercidine) derivative was prepared in an analogous way and shown to be an effective inhibitor of the E. coli, but not of the mammalian enzyme. Fluorescent complexes of amino-purine analogs with E. coli PNP were observed.
\end{abstract}

Keywords: purine nucleoside phosphorylase; nucleobase/nucleoside analogs; chemo-enzymatic synthesis; fluorescence; NMR; enzyme-substrate complexes

\section{Introduction}

Tricyclic analogs of natural purine bases and their glycosides have been applied as fluorescent probes in the investigations of structure and function of nucleic acids (DNA, RNA) and enzymes related to nucleic acid metabolism and/or those utilizing nucleotide cofactors [1-6]. The most popular probe of this kind is $1, \mathrm{~N}^{6}$-etheno-adenosine ( $\varepsilon$ Ado), prepared from adenosine reacting with chloroacetaldehyde (CAA), and related nucleotides [1]. Tri-cyclic nucleosides and nucleotides are also utilized as dimensional probes for enzymatic studies $[5,6]$. Some of the tri-cyclic analogs and their derivatives reveal promising anti-viral properties [7], recently reviewed by Janz-Wechmann et al. [8,9]. They are 
known to reveal substrate or inhibitory activities towards many enzymes of purine metabolism [2], and they are important intermediates in the process of chemical mutagenesis [10,11].

Purine-nucleoside phosphorylase (PNP, E.C. 2.4.2.1) catalyzes a reversible phosphorolysis of many nucleosides to the respective bases [12]. It belongs to a group of enzymes involved in the purine salvage pathway, present in the majority of higher organisms [12], which is the only source of these indispensable building blocks of DNA and RNA for microorganisms lacking de novo purine nucleoside synthesis. PNP is responsible for the regulation of the nucleoside concentrations within the living cells, and it is a target of various types of pharmaceutical interventions [12,13], including gene therapy of some inherited immunological deficiencies [14] and gene therapy of solid tumors [15]. Additionally, PNP's from various sources are utilized as biocatalysts in chemo-enzymatic syntheses of various nucleoside analogs of pharmaceutical and/or analytical significance [16-20]. Our previous investigations have shown that PNP isolated from E. coli, which is known to possess a broad specificity toward various base and nucleoside analogs [16], is also active toward many tri-cyclic nitrogen bases, derived from adenine and guanine $[17,21,22]$, producing in the phosphate free media many potentially useful ribosides, using $\beta$-D-ribose-1-phosphate (R1P) as a ribose source. The reverse, phosphorolytic reactions are, in some cases, as rapid as the analogous reactions with natural substrates, like adenosine or guanosine [21,22], and therefore can possess analytical applications.

The purpose of the present work is to examine some tri-cyclic amino-nucleobase analogs, in particular etheno derivatives of 2-aminopurine ( $(2 \mathrm{AP})$ and its riboside [23] and 7-deazadenosine (tubercidine [24,25], see Figure 1), as potential substrates and/or inhibitors of PNP, and possibly obtain in this way highly fluorescent compounds, useful for the future research, including study of enzyme-substrate and enzyme-inhibitor complexes. We have also extended spectral examination of the above-mentioned etheno-derivatives to include the respective tautomeric and ionic forms, the latter being important intermediates in enzymatic catalysis, with applications in the process of pharmaceutical design [26,27].<smiles>c1cn2cc3nc[nH]c3nc2n1</smiles><smiles>[R]n1cnc2cn3ccnc3nc21</smiles>

3<smiles>[R]n1ccn2cc3ncnc-3nc12</smiles>

4<smiles></smiles>

2<smiles>[R]n1ccn2c3ncnc-3cnc12</smiles>

5<smiles></smiles>

Figure 1. Structures of the nucleobase and nucleoside analogs investigated in this work: $1, \mathrm{~N}^{2}$-etheno-2-aminopurine (1), $\mathrm{N}^{2}, 3$-etheno-2-aminopurine (2), and the ribosides of the $\varepsilon 2 \mathrm{AP}$ isomers (3-5, $R=\beta$-D-ribofuranosyl). Compound 6 is $1, \mathrm{~N}^{6}$-etheno-tubercidine $(\mathrm{R}=\beta$-D-ribo-furanosyl). Only one tautomeric form of the bases is shown for simplicity. Note that the purine numbering is applied (except for the etheno-group atoms, numbered as 10 and 11). 


\section{Results}

\subsection{Reaction of Chloroacetaldehyde with 2-Aminopurine and Its Riboside}

2-Aminopurine riboside reacts rapidly with chloroacetaldehyde (CAA) at room temperature and weakly acidic $\mathrm{pH}$, to give essentially one main product [23], identified as a linear adduct of CAA $\left(1, \mathrm{~N}^{2}\right.$-etheno-2-aminopurine- $\mathrm{N}^{9}-\beta$-D-riboside, (3)), readily crystallized from the neutralized reaction mixture. This product is moderately fluorescent in the visible part of the spectrum (see Table 1). The assignment of the ${ }^{1} \mathrm{H}$ - and ${ }^{13} \mathrm{C}$-NMR signals is shown in Table 2 . There are also traces of a second, highly fluorescent product, with spectral characteristics similar to the minor product of the reaction of 2-aminopurine with CAA (see next paragraph), but we were unable to isolate this compound in sufficient quantities.

The reaction of 2-aminopurine (free base) with CAA was fairly rapid at $\mathrm{pH} \sim 4.5$ (ca. $24 \mathrm{~h}$ ), and gave two products (for the assignment of the NMR signals see Table 2). The major product, purified by re-crystallization, has been identified as $1, \mathrm{~N}^{2}$-etheno-2-aminopurine $\left(1, \mathrm{~N}^{2}-\varepsilon 2 \mathrm{AP}(\mathbf{1})\right)$, with spectral (UV and fluorescence) characteristics very similar to those of the respective $\mathrm{N}^{9}$-riboside, described by Virta et al. [23]. Additionally, we have found a minor ( 20\%), but highly fluorescent product, identified as $\mathrm{N}^{2}$,3-etheno-2-aminopurine $\left(\mathrm{N}^{2}, 3-\varepsilon 2 \mathrm{AP},(2)\right)$, exhibiting excellent substrate properties towards PNP (see below). Both identified compounds revealed two $\mathrm{pK}_{\mathrm{a}}$ values, one related to protonation (5-6.5) and the other to acidic dissociation of the imidazole proton ( $>8$, see Table 1$)$, thus confirming the identification of the products.

\subsection{Properties of Two Isomers of Etheno-2-Aminopurine}

The electronic absorption spectra of the two 2-aminopurine etheno derivatives are presented below (Figure 2), and summarized in Table 1. The spectra of the linear isomer 1 under neutral conditions (phosphate buffer, $\mathrm{pH} 7$ ) and in acid are strikingly similar to those of the $\mathrm{N}^{9}$-riboside 3 , published by Virta et al. [23], and are markedly red-shifted relative to analogous spectra of all adenine or guanine derivatives (cf. [21,22]). In basic media, the spectrum is shifted even more, showing maximum absorbance at $367 \mathrm{~nm}$ (Figure 2, Table 1). The minor, non-linear product (2) revealed low-energy absorption band near 300-320 nm.

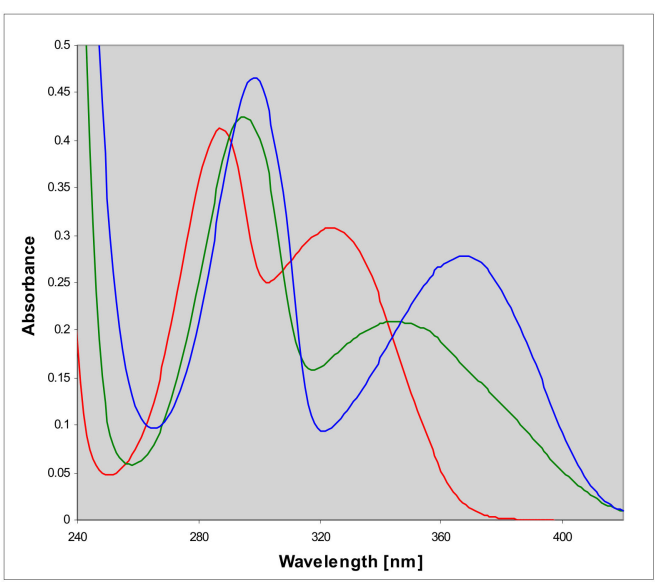

(a)

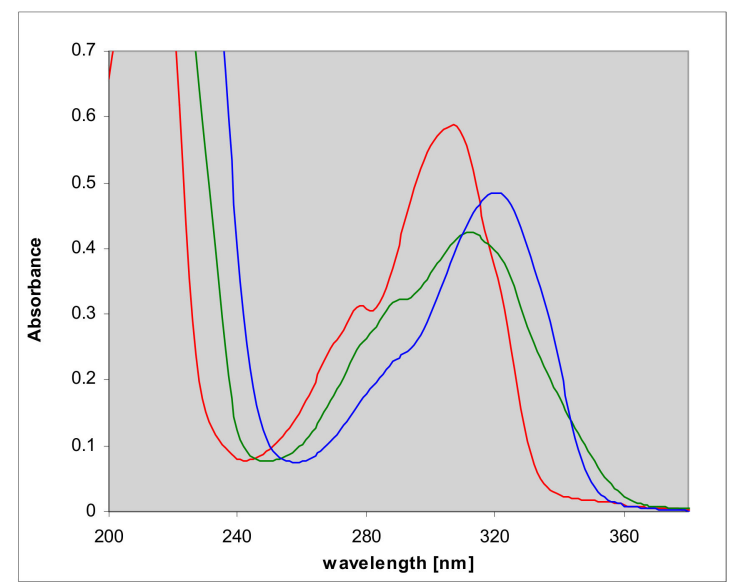

(b)

Figure 2. Electronic absorption spectra of (a) $1, \mathrm{~N}^{2}$-etheno-2-aminopurine (1) and (b) $\mathrm{N}^{2}, 3-$ etheno-2-aminopurine (2) in aqueous medium at various $\mathrm{pH}$ : red curves- $\mathrm{pH}$ 3; green $-\mathrm{pH} 7$; blue-H 11.

Both abovementioned products revealed moderate to intense fluorescence in neutral aqueous medium, centered at ca. $470\left(1, \mathrm{~N}^{2}\right.$-etheno-2-aminopurine (1)) and $405 \mathrm{~nm}\left(\mathrm{~N}^{2}\right.$,3-etheno-2-aminopurine 
(2)), with yields approximately 0.18 and 0.73 , respectively (see Figure 3 and Table 1 ). The fluorescence spectra of both isomers were to some extent excitation-dependent (Figure 3), and their fluorescence decays revealed non-exponential behavior (Table 1), the facts possibly related to protomeric equilibria in the ground state (see Discussion). The ionic forms of the two tri-cyclic bases are also fluorescent (see Figure 4, below). Anionic and cationic forms of 1, $\mathrm{N}^{2}$-etheno-2-aminopurine (1) emit in the same region as the neutral molecule $(460-470 \mathrm{~nm}$ ), but with different yields (Figure $4 \mathrm{a}$, Table 1). The largest Stokes' shift is observed for the cationic species $\left(9300 \mathrm{~cm}^{-1}\right)$. The respective excitation spectra are virtually in line with UV absorption of each form. The anionic form of the non-linear isomer $\mathbf{2}$ is strongly fluorescent at $390 \mathrm{~nm}$ (Figure $4 \mathrm{~b}$, blue line), while the cationic form of this compound exhibits two-band fluorescence, with Stokes' shift for the low-energy band exceeding $10,000 \mathrm{~cm}^{-1}$ (see Figure $4 \mathrm{~b}$, red curve).

Table 1. Ionization constants ( $\mathrm{pK}_{\mathrm{a}}$ values, determined spectrophotometrically) and spectral parameters for neutral and ionic forms of the investigated compounds ( $\mathrm{n}$-neutral form; $\mathrm{c}$-cation; a-anion). $\mathrm{Nd}=$ not determined .

\begin{tabular}{|c|c|c|c|c|c|c|c|}
\hline \multirow[t]{2}{*}{ Compound } & \multirow[t]{2}{*}{$\mathrm{pK}_{\mathrm{a}}$} & form $(\mathrm{pH})$ & \multicolumn{2}{|c|}{$\begin{array}{c}\text { UV } \\
\text { Absorption } \\
\lambda_{\max }(\mathrm{nm}) \varepsilon_{\max }\end{array}$} & \multicolumn{2}{|c|}{$\begin{array}{l}\text { Fluorescence } \\
\lambda_{\max }(\mathrm{nm}) \varphi\end{array}$} & $\tau[\mathrm{ns}]$ \\
\hline & & $\mathrm{n}(7)$ & 348 & 2560 & 472 & 0.18 & $6.9 ; 10.3$ \\
\hline \multirow[t]{2}{*}{ 1, $\mathrm{N}^{2}$-etheno-2-aminopurine $(\mathbf{1})$} & $5.6 ; 8.2$ & $c(3)$ & 285 & 5050 & 467 & $\sim 0.04$ & $\mathrm{Nd}$ \\
\hline & & $\mathrm{a}(11)$ & 367 & 3500 & 463 & $\sim 0.40$ & $\mathrm{Nd}$ \\
\hline \multirow{2}{*}{$\mathrm{N}^{2}-\beta-\mathrm{D}$-Ribofuranoside (4) } & \multirow{2}{*}{6.3} & $\mathrm{n}(8)$ & 338 & 4260 & 406 & 0.73 & $\mathrm{Nd}$ \\
\hline & & $c(3)$ & 326 & $\mathrm{Nd}$ & 406 & 0.73 & $\mathrm{Nd}$ \\
\hline \multirow{2}{*}{$\mathrm{N}^{9}-\beta$-D-Ribofuranoside (3) } & \multirow{2}{*}{-} & $\mathrm{n}(8)$ & 295 & $5700^{1}$ & 463 & 0.14 & $\mathrm{Nd}$ \\
\hline & & $c(3)$ & 318 & 6120 & 465 & 0.06 & $\mathrm{Nd}$ \\
\hline \multirow{3}{*}{$\mathrm{N}^{2}$,3-etheno-2-aminopurine (2) } & \multirow{3}{*}{$5.0 ; \sim 9.5$} & $\mathrm{n}(7)$ & 315 & $\sim 5600$ & 406 & 0.73 & $3.8 ; 8.5$ \\
\hline & & $c(2.5)$ & 306 & $\sim 7700$ & 455 & $\sim 0.30$ & $\mathrm{Nd}$ \\
\hline & & $\mathrm{a}(12)$ & 320 & $\sim 6700$ & 390 & $\sim 0.40$ & $\mathrm{Nd}$ \\
\hline \multirow{2}{*}{$N^{2}-\beta-D-R i b o f u r a n o s i d e ~(5)$} & \multirow{2}{*}{6.15} & $\mathrm{n}(8)$ & 315 & $\sim 10,700$ & 357 & 0.29 & 2.15 \\
\hline & & $c(3)$ & 310 & $\sim 9400$ & 373 & $\sim 0.15$ & $\mathrm{Nd}$ \\
\hline \multirow{2}{*}{$1, \mathrm{~N}^{6}$-ethenotubercidine $(6)$} & \multirow{2}{*}{5.2} & $\mathrm{n}(7)$ & 288 & $5800^{2}$ & 415 & $0.53^{2}$ & $\mathrm{Nd}$ \\
\hline & & $c(3)$ & 281 & 8700 & 415 & $\mathrm{Nd}$ & $\mathrm{Nd}$ \\
\hline
\end{tabular}

${ }^{1}$ Data from Virta et al. [23] and ${ }^{2}$ from Seela et al. [25] for 2'-deoxytubercidine.

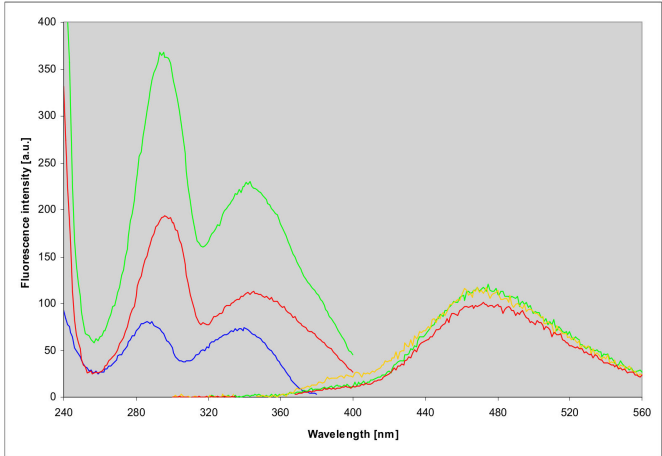

(a)

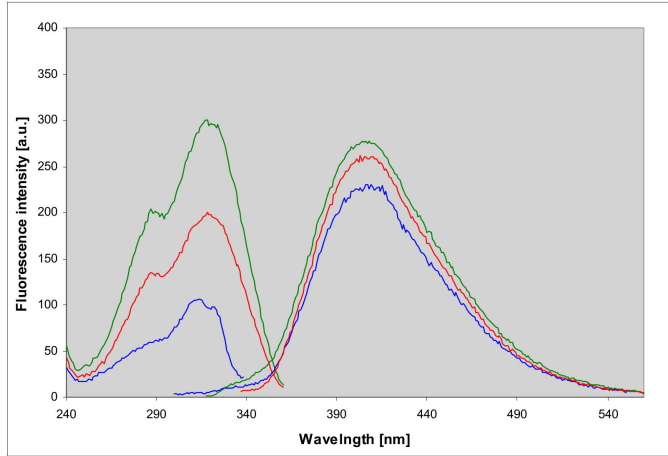

(b)

Figure 3. Fluorescence emission and corrected fluorescence excitation spectra of: (a) 1, $\mathrm{N}^{2}$-etheno-2-aminopurine (1), and (b) $\mathrm{N}^{2}$,3-etheno-2-aminopurine (2) in neutral aqueous solution. Emission spectra were measured with excitations at 310, 330 and $360 \mathrm{~nm}$ (green, yellow and red; left panel), and 310, 330 and $350 \mathrm{~nm}$ (green, blue and red, right panel), and excitation spectra with observations at 400, 440 and $480 \mathrm{~nm}$ (blue, green and red, left panel) and at 380, 400 and $440 \mathrm{~nm}$ (blue, green and red, right panel). 


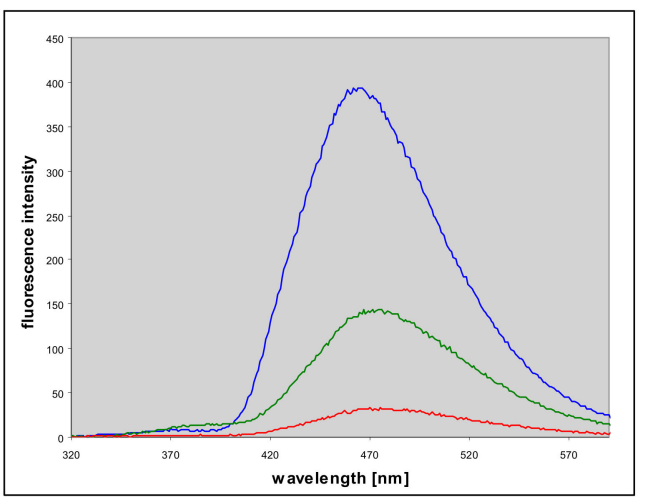

(a)

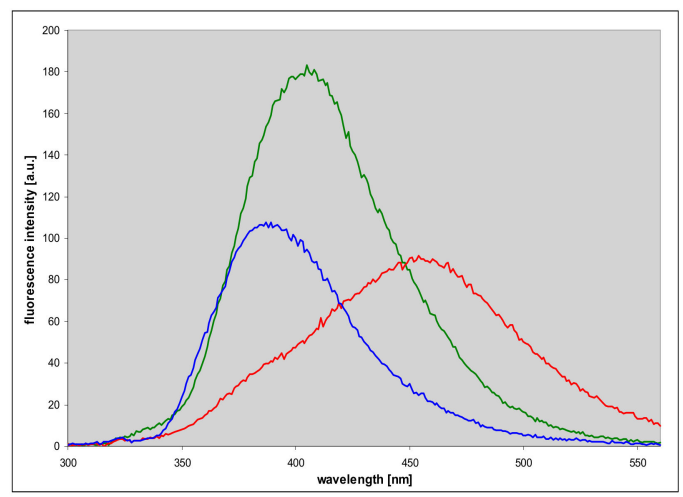

(b)

Figure 4. Fluorescence spectra of (a) 1, $\mathrm{N}^{2}$-etheno-2-aminopurine (1) and (b) $\mathrm{N}^{2}, 3$-etheno-2-aminopurine (2) in aqueous medium at various $\mathrm{pH}$ : red curves, $\mathrm{pH}$ 3; green, $\mathrm{pH} 6.5$ (a) and 7 (b); blue- $-\mathrm{pH}$ 11.5. Excitation was at $300 \mathrm{~nm}$ (a) and $290 \mathrm{~nm}$ (b). The spectra of the ionic forms are virtually excitation-independent.

Table 2. ${ }^{1} \mathrm{H}$ - and ${ }^{13} \mathrm{C}-\mathrm{NMR}$ chemical shifts in parts per million $( \pm 0.001)$ of the etheno derivatives of 2-aminopurine ( $\varepsilon 2 \mathrm{AP})$ and their $\beta$-D-ribosides (see Materials and Methods for details). Chemical shift labels follow the naming convention of [28], extended for the etheno protons (see Figure 1).

\begin{tabular}{|c|c|c|c|c|c|}
\hline Nucleus & $\begin{array}{c}1, \mathrm{~N}^{2}-\varepsilon 2 \mathrm{AP} \\
(1)\end{array}$ & $\begin{array}{c}1, \mathrm{~N}^{2}-\varepsilon 2 \mathrm{AP}- \\
\mathrm{N}^{9} \text {-ribofuranoside } \\
(3)\end{array}$ & $\begin{array}{c}1, \mathrm{~N}^{2}-\varepsilon 2 \mathrm{AP}- \\
\mathrm{N}^{2} \text {-ribofuranoside }\end{array}$ & $\begin{array}{c}\mathrm{N}^{2}, 3-\varepsilon 2 \mathrm{AP} \\
(2)\end{array}$ & $\begin{array}{c}\mathrm{N}^{2}, 3-\varepsilon 2 \mathrm{AP}- \\
\mathrm{N}^{2} \text {-ribofuranoside } \\
\text { (5) }\end{array}$ \\
\hline H6 & 9.445 & 9.541 & 9.246 & 8.879 & 8.992 \\
\hline H8 & 8.513 & 8.768 & 8.403 & 8.408 & 8.067 \\
\hline $\mathrm{H} 10^{1}$ & 7.624 & 7.661 & 7.987 & 8.115 & 8.356 \\
\hline $\mathrm{H} 11^{1}$ & 7.895 & 7.931 & 8.092 & 7.719 & 8.351 \\
\hline $\mathrm{H}^{\prime}$ & - & 5.969 & 6.212 & - & 6.286 \\
\hline $\mathrm{H} 2^{\prime}$ & - & 4.617 & 4.418 & - & 4.415 \\
\hline $\mathrm{OH} 2^{\prime}$ & - & 5.531 & 5.592 & - & 5.612 \\
\hline $\mathrm{H}^{\prime}$ & - & 4.189 & 4.152 & - & 4.177 \\
\hline $\mathrm{OH}^{\prime}$ & - & 5.217 & 5.343 & - & 5.249 \\
\hline $\mathrm{H} 4^{\prime}$ & - & 3.962 & 3.985 & - & 4.010 \\
\hline $\mathrm{H} 5^{\prime} / \mathrm{H}^{\prime \prime}$ & - & $3.581 / 3.690$ & $3.601 / 3.694$ & - & $3.630 / 3.733$ \\
\hline $\mathrm{OH} 5^{\prime}$ & - & 5.090 & 5.162 & - & 5.210 \\
\hline $\mathrm{C} 2$ & 147.470 & 146.868 & 141.394 & 147.740 & 139.817 \\
\hline $\mathrm{C} 4$ & 152.793 & 150.122 & 165.789 & 143.330 & 147.377 \\
\hline C5 & 126.637 & 127.994 & 134.105 & 116.873 & 132.921 \\
\hline $\mathrm{C} 8$ & 149.972 & 149.029 & 167.161 & 142.398 & 155.724 \\
\hline $\mathrm{C} 10^{1}$ & 133.727 & 134.305 & 111.629 & 107.780 & 108.777 \\
\hline $\mathrm{C} 11^{1}$ & 110.641 & 111.080 & 118.837 & 133.172 & 119.946 \\
\hline C6 & 125.239 & 127.102 & 123.368 & 138.144 & 144.668 \\
\hline $\mathrm{C}^{\prime}$ & - & 87.495 & 88.07 & - & 89.037 \\
\hline $\mathrm{C} 2^{\prime}$ & - & 73.529 & 74.439 & - & 74.969 \\
\hline $\mathrm{C}^{\prime}$ & - & 70.568 & 70.471 & - & 70.151 \\
\hline $\mathrm{C} 4^{\prime}$ & - & 85.706 & 85.761 & - & 85.798 \\
\hline$C 5^{\prime}$ & - & 61.603 & 61.443 & - & 61.059 \\
\hline
\end{tabular}

${ }^{1}$ Due to the possibility of non-vanishing five-bond ${ }^{1} \mathrm{H}^{13} \mathrm{C}$ couplings in aromatic structures the assignment of the $\mathrm{H} 10 / \mathrm{C} 10$ and $\mathrm{H} 11 / \mathrm{C} 11$ pairs is tentative and may be reversed.

\subsection{Enzymatic Ribosylation of the Etheno-2-Aminopurine Isomers Using Various Forms of PNP}

Both isomers of the etheno-2-aminopurine are substrates for PNP from E. coli in the reverse (synthetic) pathway with R1P as a ribosyl donor. Ribosylation of 1, $\mathrm{N}^{2}$-etheno-2-aminopurine (1) as well as $\mathrm{N}^{2}$,3-etheno-2-aminopurine (2) led to substantial changes in the UV absorption (Figure 5) and fluorescence (Figure 6) spectra, suggesting that the ribosylation sites may be different from the proton location in the respective base (the latter is possibly $\mathrm{N}^{9}$ ). We have also noted a striking similarity between UV absorption spectrum of the ribosylation products and the fluorescence excitation spectra 
of the minor tautomers of the respective bases, measured with observations at the blue edge of the emission spectrum (cf. Figures 2 and 3). The ribosylation rate for the non-linear $\varepsilon 2 \mathrm{AP}$ isomer, $\mathrm{N}^{2}$,3-etheno-2-aminopurine (2), is ca. 40-fold higher than that for the linear isomer 1, and comparable to the ribosylation rate of guanine, measured in the same conditions (Table 3).

Ribosides of 1, $\mathrm{N}^{2}$-etheno-2-aminopurin (1) as well as $\mathrm{N}^{2}, 3$-etheno-2-aminopurine (2), generated using the E. coli PNP, were subjected to HPLC purification on a milligram scale, and their identification and properties are described in the next paragraph.

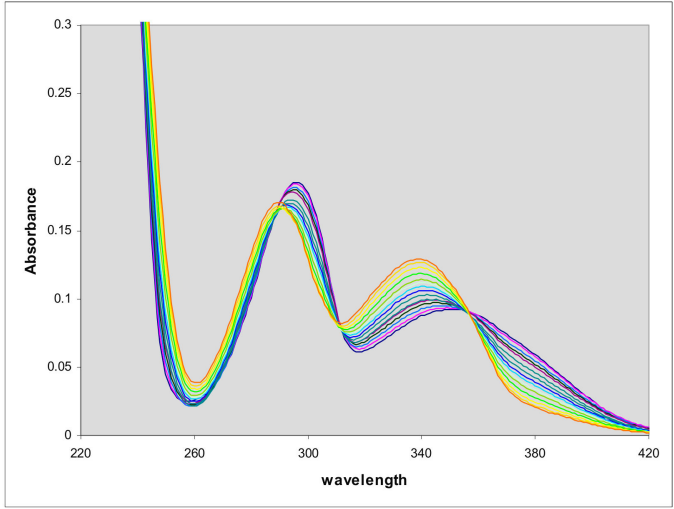

(a)

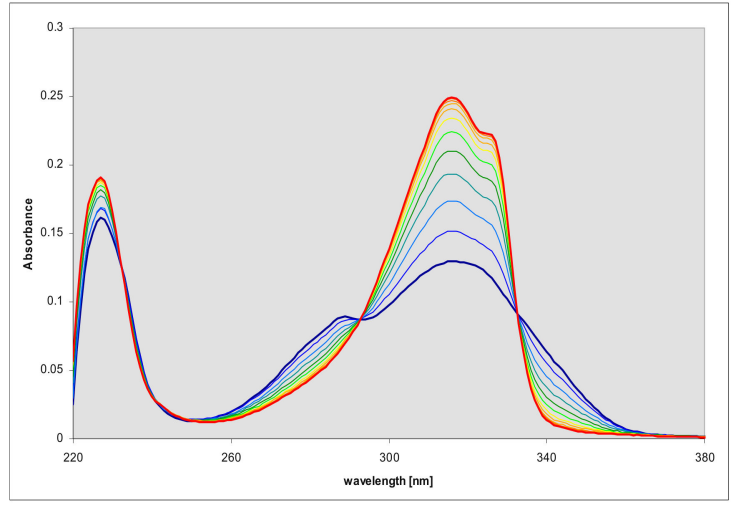

(b)

Figure 5. UV absorption changes observed during the enzymatic ribosylation of (a) $1, \mathrm{~N}^{2}$-etheno2-aminopurine (1) with $0.5 \mathrm{mM} \mathrm{R1P}$, catalyzed by PNP from E. coli; (b) enzymatic ribosylation of $\mathrm{N}^{2}$,3-etheno-2-aminopurine (2) by the same enzyme under identical conditions. Initial curves are in blue, and the final curves in red. Time intervals were $5 \mathrm{~min}$ for (a) and $2 \mathrm{~min}$ for (b).

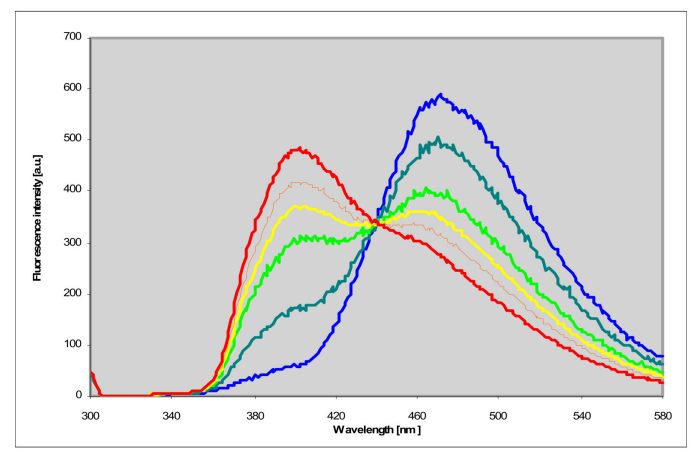

(a)

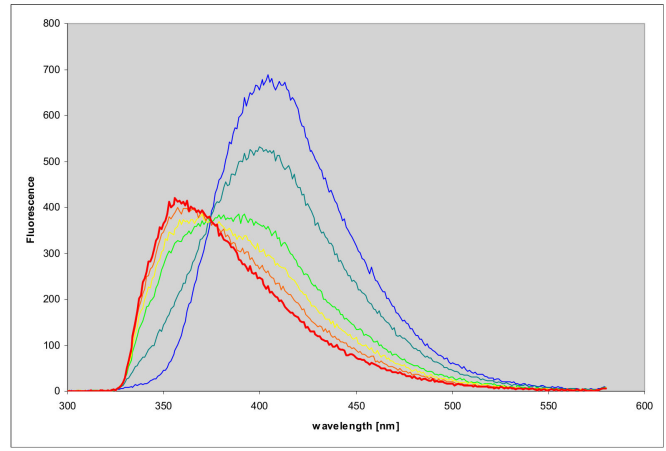

(b)

Figure 6. Fluorescence changes observed during the enzymatic ribosylation of (a) 1, $\mathrm{N}^{2}$-etheno2-aminopurine (1) with $0.5 \mathrm{mM}$ R1P, catalyzed by PNP from E. coli; (b) $\mathrm{N}^{2}$,3-etheno-2-aminopurine (2) by the same enzyme under identical conditions. Initial curves are in blue, and the final curves in red.

Kinetic parameters of the synthetic (ribosylation) reaction, catalyzed by the wild-type and mutated forms of PNP, were determined using standard procedures, and are summarized in Table 3. There are some minor differences between wild-type enzymes (E. coli and calf PNP) and forms mutated in the active site, but without qualitative differences, observed previously for some purine analogs [21,22]. Generally, kinetic parameters for ribosylation of 2 by E. coli PNP and its mutated forms do not differ markedly from those determined earlier for natural purines [12], and the $K_{m}$ values are close to $10 \mu \mathrm{M}$, hence comparable to those observed for guanine ribosylation under the same conditions.

It may also be of interest that the trimeric calf spleen PNP, much more demanding in respect to substrate structures than the hexameric E. coli enzyme [12], ribosylates $\mathrm{N}^{2}, 3$-etheno-2-aminopurine (2) 
with moderate rate (Table 3), but is apparently inactive towards the second (linear) isomer $\mathbf{1}$. It may be of interest that $\mathrm{N}^{2}, 3$-etheno-2-aminopurine (2) is fairly rapidly ribosylated by the calf PNP, mutated in the active site (N243D). But the ribosylation goes in an essentially similar way as with the E. coli PNP, that is, giving the identical single product (Table 3).

Table 3. Kinetic parameters for the enzymatic ribosylation of selected etheno-purine derivatives in 40 mM HEPES buffer, pH 7, by $\alpha$-D-ribose-1-phosphate, using various forms of PNP (wt = wild type; nr-no reaction detected; nd-not determined). Standard errors are estimated to be $\sim 15 \%$.

\begin{tabular}{|c|c|c|c|c|}
\hline Substrate & Enzyme (PNP Source) & $K_{m}(\mu M)$ & $\mathrm{V}_{\max }{\text { (Relative })^{1}}^{1}$ & Ribosylation Site \\
\hline 1, $\mathrm{N}^{2}$-etheno-2-aminopurine $(\mathbf{1})$ & calf-wt & $\mathrm{nr}$ & $<0.1$ & - \\
\hline “ & calf $-\mathrm{N} 243 \mathrm{D}$ & nd & traces & nd \\
\hline “ & E. coli-wt & $<10$ & $\sim 1$ & mostly $\mathrm{N}^{2}$ \\
\hline $\mathrm{N}^{2}$,3-etheno-2-aminopurine (2) & calf-wt & $\sim 8$ & $\sim 5$ & predominantly $\mathrm{N}^{2}$ \\
\hline " & calf-N243D & 110 & 29 & predominantly $\mathrm{N}^{2}$ \\
\hline “ & E. coli-wt & 11 & 20 & predominantly $\mathrm{N}^{2}$ \\
\hline " & E. coli-D204N & 12 & 30 & predominantly $\mathrm{N}^{2}$ \\
\hline “ & E. coli-S90A & $\sim 20$ & 23 & predominantly $\mathrm{N}^{2}$ \\
\hline
\end{tabular}

${ }^{1}$ Relative to guanine ribosylation rate under identical conditions (set as 100).

\subsection{Properties and Identification of the Enzymatically Produced Ribosides}

Reaction of 2-aminopurine riboside with chloroacetaldehyde gives $\mathrm{N}^{9}$-riboside (3) of the linear isomer of etheno-2-aminopurine (for the assignment of the ${ }^{1} \mathrm{H}$ and ${ }^{13} \mathrm{C}-\mathrm{NMR}$ signals see Table 2 ), revealing spectral properties very similar to those of the respective base (see Section 3.2), but with a single emission band (465 nm) and a single decay time (Table 1). By contrast, the main product of enzymatic ribosylation of $1, \mathrm{~N}^{2}$-etheno-2-aminopurine, 4, is characterized by the emission at $400 \mathrm{~nm}$, single decay time, and the UV absorption shifted to the blue by over $20 \mathrm{~nm}$ (see Figures 5 and 6 , left panels, and Figure 7). This riboside undergoes protonation with $\mathrm{pK}_{\mathrm{a}} \sim 6.3$ (see Supplementary Materials, Figure S1). The compound has been subjected to purification using semi-preparative HPLC, and identified as $1, \mathrm{~N}^{2}$-etheno-2-aminopurine- $\mathrm{N}^{2}$-riboside ((4), see below).

The riboside produced enzymatically from the non-linear isomer of etheno-2-aminopurine, 5, also differs spectrally from the parent base 2 . Its emission spectrum is shifted by $\sim 45 \mathrm{~nm}$ to $355 \mathrm{~nm}$, and UV absorption reveals fine structure (Figure 8). Fluorescence decay is mono-exponential, and decay time is lowered to $\sim 2 \mathrm{~ns}$, with yield $\sim 0.29$ (Table 1 ). The protonated form of the riboside is also strongly fluorescent, but we did not detect any traces of dual emission (as observed in the emission spectrum of the protonated base, see Figure 4), and the Stokes' shift was moderate (Figure 8). We conclude that the photo-transformation, observed in the protonated base as two-band emission, is absent in the riboside. 


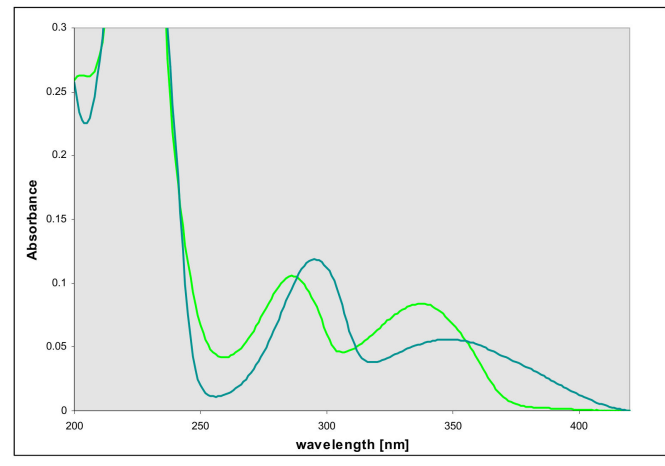

(a)

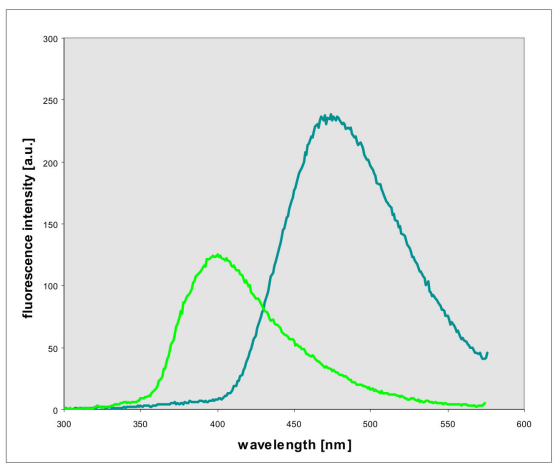

(b)

Figure 7. Comparison of (a) absorption and (b) fluorescence spectra of two ribosides of $1, \mathrm{~N}^{2}$-etheno-2-aminopurine ( 3 and 4), obtained chemically (3, dark green curves) and enzymatically 4, using E. coli PNP as a catalyst (bright green curves). Spectra measured in phosphate buffer, pH 7. Fluorescence excitation is at $290 \mathrm{~nm}$.

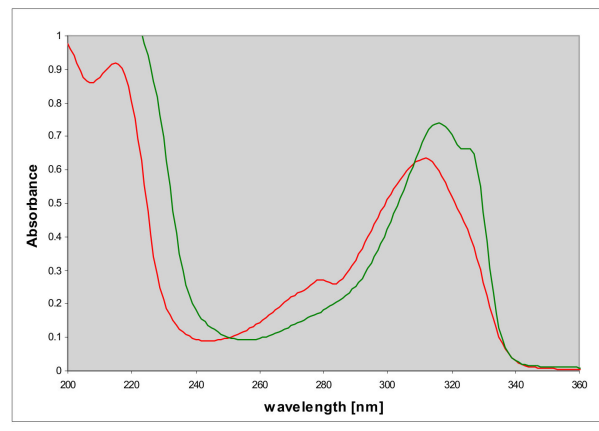

(a)

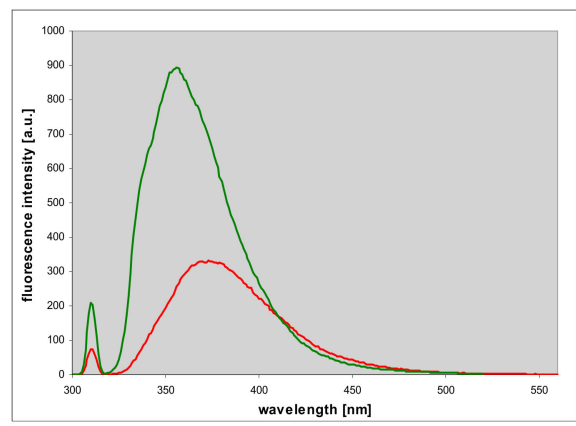

(b)

Figure 8. Electronic absorption (a) and fluorescence (b) spectra of the $\mathrm{N}^{2}, 3$-etheno-2aminopurine- $\mathrm{N}^{2}-\beta$-D-riboside (5) in aqueous media. Green lines: $\mathrm{pH} 7$, red lines: $\mathrm{pH}$ 3. Fluorescence excitation was $310 \mathrm{~nm}$.

The fluorescence decay times of all the ribosides 3-5, both $\mathrm{N}^{9}$-ribo and $\mathrm{N}^{2}$-ribo, measured at $\mathrm{pH}>7.5$, were mono-exponential, in agreement with the view that no protomeric equilibrium is possible in the ground states of the ribosides, at least at their heteroaromatic moiety. Accordingly, fluorescence excitation spectra were in line with the UV absorption. Interestingly, the emission and excitation spectra of $\mathrm{N}^{2}$-ribosides 4-5 resemble those of the minor tautomers of both isomeric bases (see Section 3.2). This leads to tentative identification of the minor tautomers of both $\mathrm{N}^{2}, 3-\varepsilon 2 \mathrm{AP}(2)$ and $1, \mathrm{~N}^{2}-\varepsilon 2 \mathrm{AP}(\mathbf{1})$ as $\mathrm{N}^{2} \mathrm{H}$ (see Discussion).

The ribosylation site of $\mathrm{N}^{2}$,3-etheno-2-aminopurine (2) via the enzymatic process was identified as $\mathrm{N}^{2}$ (for the assignment of the NMR signals in 5 see Table 2), based on the observation of non-vanishing three-bond scalar couplings between $\mathrm{H}^{\prime}$ and both $\mathrm{C} 2$ and $\mathrm{C} 11$, as well as between $\mathrm{H} 11$ and $\mathrm{C1}^{\prime}$, in the ${ }^{1} \mathrm{H}-{ }^{13} \mathrm{C}$ HSQMBC spectrum (Figure 9). In the absence of other observable scalar couplings between the ribose and the base nuclei the position $\mathrm{N}^{2}$ is the only ribosylation site congruent with this coupling pattern. The ribosylation product of the linear isomer $\mathbf{1}$ was identified as $1, \mathrm{~N}^{2}$-etheno-2-aminopurine- $\mathrm{N}^{2}$-riboside (5), based on the observation of a coupling pattern fully analogous to that of the non-linear isomer. 


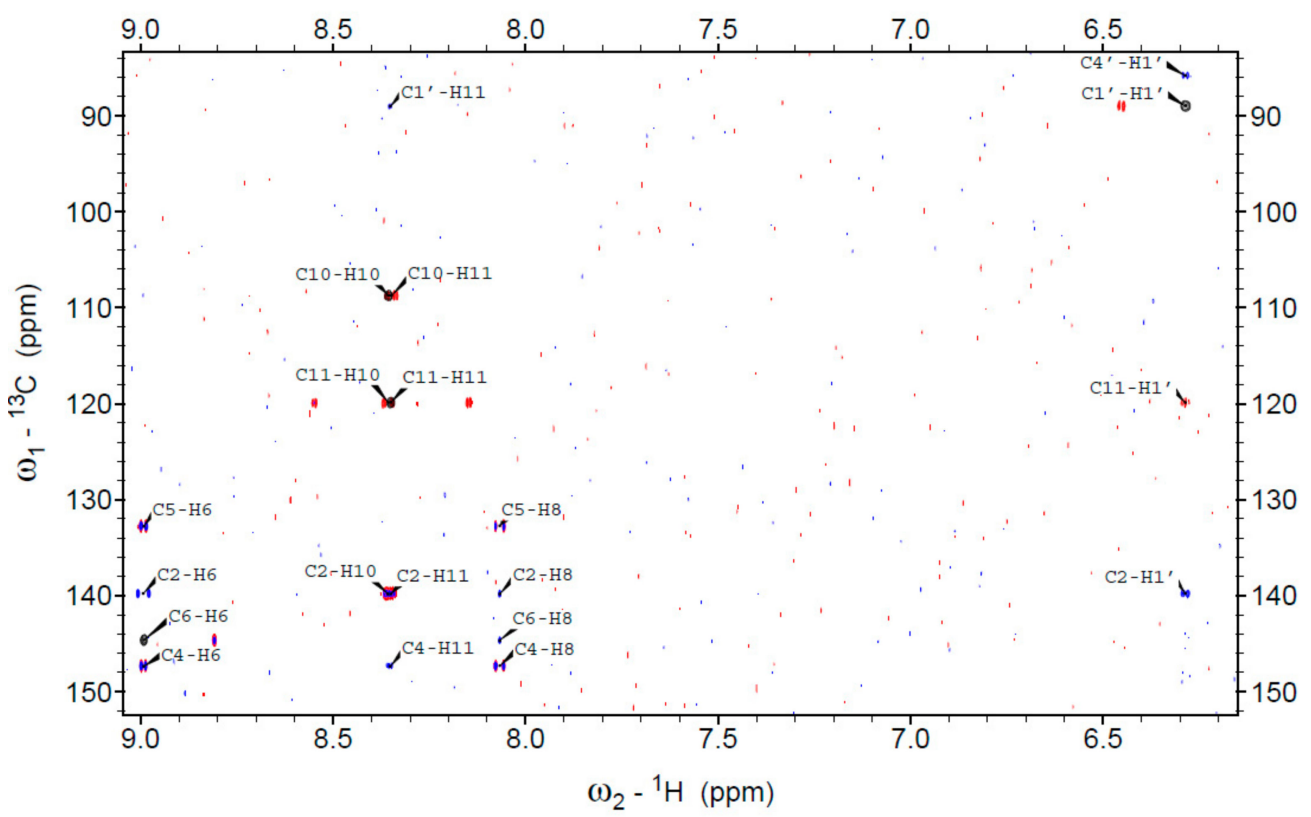

Figure 9. Aromatic and $\mathrm{H}\left(1^{\prime}\right) / \mathrm{C}\left(1^{\prime}\right)$ ribose region of the contour plots of ${ }^{1} \mathrm{H},{ }^{13} \mathrm{C}$ correlation spectra of $\mathrm{N}^{2}$,3-etheno-2-aminopurine riboside (5) in DMSO- $\mathrm{d}_{6}$ (at ${ }^{1} \mathrm{H}$ frequency of $500 \mathrm{MHz}$, at $25^{\circ} \mathrm{C}$ ) showing the cross-peaks between the ribose and nucleobase nuclei. Contours are plotted: for HSQC (black), for $8 \mathrm{~Hz}$ optimized HSQMBC (red), and for $2 \mathrm{~Hz}$ optimized HSQMBC (blue). All peaks are marked at the center of the multiplet and labeled according to the assigned nuclei (Table 2).

The ribosides are fairly stable in solution, but we were unable to crystallize them due to small amounts obtained. They were stored as frozen in neutral aqueous solutions.

\subsection{Phosphorolysis of The Ribosides with Various Forms of PNP}

The highly fluorescent $\mathrm{N}^{2}, 3$-etheno-2-aminopurine- $\mathrm{N}^{2}-\beta$-D-riboside (5), generated enzymatically (Section 3.3) is readily phosphorolyzed in the phosphate buffer by both E. coli and calf PNP. The reaction rates are in the case of E. coli enzyme comparable or even higher than that of guanosine phosphorolysis (Table 4), while those obtained for calf PNP are moderate. The observed spectral changes are reverse in respect to those presented of Figures 4 and 5 for the synthetic process (see Supplementary Materials, Figure S2), and lead to very pronounced fluorogenic effect (not shown). Kinetic analysis revealed relative low $\mathrm{K}_{\mathrm{m}}$ values for these reactions (Table 4), although they are somewhat higher than those for the synthetic reactions (Table 3).

Table 4. Kinetic parameters for the enzymatic phosphorolysis of selected etheno-2-aminopurine ribosides in $40 \mathrm{mM}$ phosphate buffer, $\mathrm{pH}$ 7, using various forms of PNP. Standard errors are estimated to be $\sim 20 \%$; $\mathrm{nr}=$ no reaction observed.

\begin{tabular}{|c|c|c|c|}
\hline Substrate & Enzyme $^{2}$ & $K_{m}(\mu M)$ & $\mathrm{V}_{\text {max }}(\text { relative })^{1}$ \\
\hline $1, \mathrm{~N}^{2}$-etheno-2-aminopurine- $\mathrm{N}^{9}$ - $\beta$-D-riboside (3) & E. coli PNP-wt & $\mathrm{nr}$ & $<1$ \\
\hline 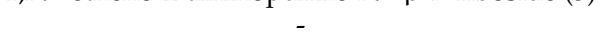 & calf PNP-wt & $\mathrm{nr}$ & $<0.1$ \\
\hline $1, \mathrm{~N}^{2}$-etheno-2-aminopurine- $\mathrm{N}^{2}-\beta$-D-riboside (4) & E. coli PNP-wt & 47 & 4 \\
\hline- & calf PNP-wt & $\mathrm{nr}$ & $<0.1$ \\
\hline $\mathrm{N}^{2}, 3$-etheno-2-aminopurine- $\mathrm{N}^{2}-\beta$-D-riboside (5) & E. coli PNP-wt & $\sim 20$ & 115 \\
\hline- & calf PNP-wt & 4.6 & 3 \\
\hline
\end{tabular}

${ }^{1}$ Relative to $\mathrm{V}_{\max }$ of guanosine phosphorolysis under the same conditions $(=100) ;{ }^{2} \mathrm{wt}=$ wild type.

We expect that the human PNP, which is quite similar to the calf enzyme [12], will also react with $\mathrm{N}^{2}$,3-etheno-2-aminopurine- $\mathrm{N}^{2}-\beta$-D-riboside (5), giving the highly fluorescent base 2 as a reaction product, with possible applications to analytical or clinical biochemistry. This point will be addressed in 
a separate paper. The ribosylated linear isomer, identified as $1, \mathrm{~N}^{2}$-etheno-2-aminopurine- $\mathrm{N}^{2}$-riboside (4) reacts much slower, and only with the E. coli PNP as a catalyst (Table 4).

\subsection{Properties of $1, N^{2}$-Etheno-Tubercidine}

Tubercidine (7-deazaadenosine) is a known antibiotic and an inhibitor of the bacterial (hexameric) forms of PNP [12]. It is also a substrate of some thermostable bacterial PNPs at higher temperatures $[29,30]$. The reaction of tubercidine and $2^{\prime}$-deoxytubercidine with chloroacetaldehyde gives the respective 1, $\mathrm{N}^{6}$-etheno derivatives in good yields [24,25]. 1, $\mathrm{N}^{6}$-Etheno-deoxytubercidine exhibits intense fluorescence at $\sim 400 \mathrm{~nm}$, similar to that of the analogous $1, \mathrm{~N}^{6}$-ethenoadenosine [25].

We have found that $1, \mathrm{~N}^{6}$-etheno-tubercidine (6) competitively inhibits phosphorolysis of purine nucleosides, catalyzed by the $E$. coli enzyme. The inhibition constant, $\mathrm{K}_{\mathrm{i}} \sim 4.5 \mu \mathrm{M}$, is comparable to that of tubercidine itself [12], some formycin derivatives [31,32], and other good inhibitors of this enzyme [12]. Etheno-tubercidine (6) is therefore a good candidate to observe enzyme-ligand complexes by spectral methods, as shown below. No inhibition of the calf PNP was observed, at least in moderate concentrations (up to $50 \mu \mathrm{M}$ ) that we used.

\subsection{Fluorescence of Enzyme-Ligand Complexes}

Titration of the E. coli PNP with $\mathrm{N}^{2}$,3-etheno-2-aminopurine (2) in the presence of phosphate leads to moderate quenching of the protein fluorescence at $305 \mathrm{~nm}$ and formation of fluorescent complexes, visible both in emission and in excitation spectra (see Figure 10). Additionally, the fluorescence excitation spectra reveal fluorescence energy transfer (FRET) from the protein to the complexed ligand, since they show marked enhancement in the region $270-280 \mathrm{~nm}$, where the tyrosine residues of the PNP molecule absorb (Figure 10). The fluorescence quantum yield of the bound ligand is very high and comparable to that of the free molecule ( 0.73 , see Table 1$)$, as evidenced by difference spectra (no negative contribution at the long-wavelength tail of the spectrum).

The respective difference spectra (Figure 10c,d) confirm moderate quenching of protein fluorescence (right-hand side), evidence of FRET (left), and appearance of the complex emission at 380-400 nm, revealing some fine structure, which is absent in the free ligand spectrum. We did not observe analogous complexes in the absence of phosphate, in spite of the low Michaelis' constants obtained for the synthetic reaction (Table 3).

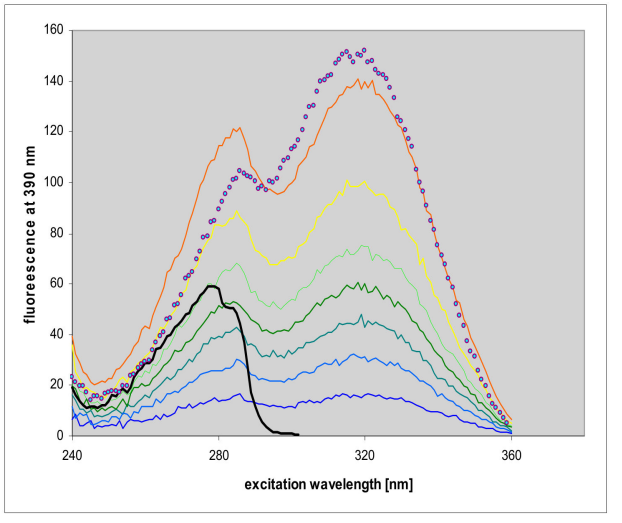

(a)

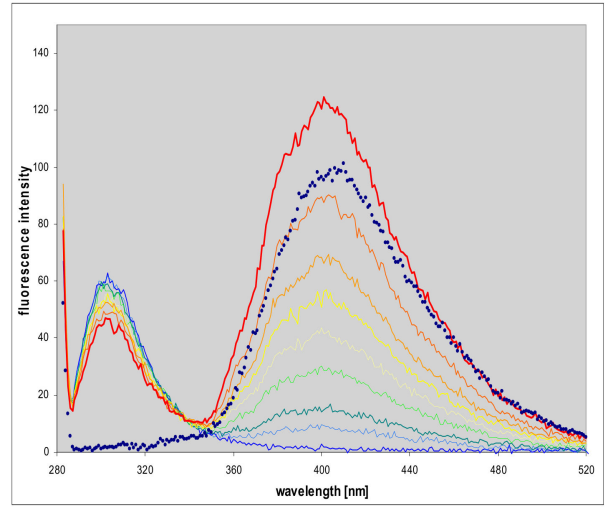

(b)

Figure 10. Cont. 


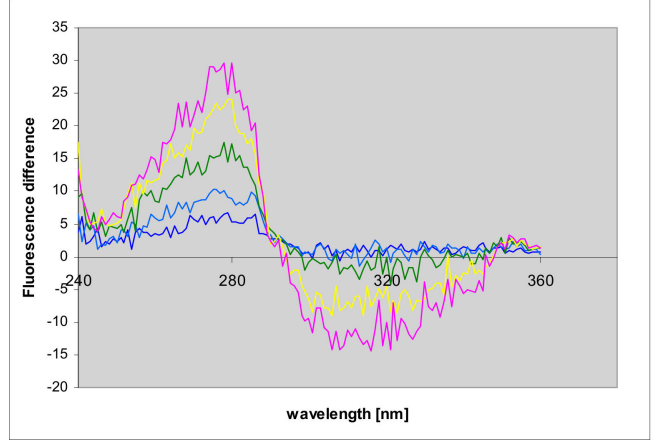

(c)

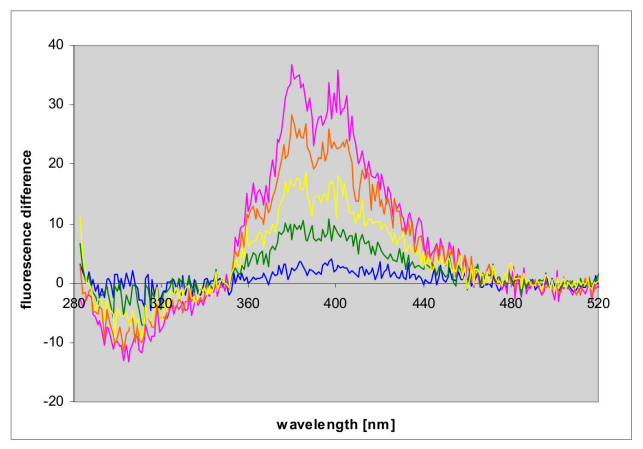

(d)

Figure 10. Changes in fluorescence excitation (a) and emission spectra (b), observed during the titration of $E$. coli PNP with $\mathrm{N}^{2}, 3$-etheno-2-aminopurine (2). The excitation spectra were observed at $390 \mathrm{~nm}$, and for emission spectra excitation was at $280 \mathrm{~nm}$. Spectra of the free ligand $(3.5 \mu \mathrm{M})$ are given for comparison (points). Excitation spectrum of the protein, monitored at $310 \mathrm{~nm}$, is given in black. Conditions: $40 \mathrm{mM}$ phosphate, $\mathrm{pH} 7$, at $20^{\circ} \mathrm{C}$. Concentration of protein was $10.1 \mu \mathrm{M}$ (per subunit); that of the titrant was 0 to $3.5 \mu \mathrm{M}$. Lower panels: Fluorescence difference spectra, calculated from data presented on panels (a) and (b), (c) difference excitation (observed at $380 \mathrm{~nm}$ ), (d) difference emission spectra, excited at $275 \mathrm{~nm}$. Substrate concentrations are $0.17,0.69,1.37,2.36$ and $3.31 \mu \mathrm{M}$.

Etheno-tubercidine (6) forms somewhat similar fluorescent complexes with the E. coli PNP. As shown below, FRET from the protein to the ligand is evident in the excitation spectra (Figure 11), and the ligand fluorescence blue shifted from 415 to ca. $390 \mathrm{~nm}$ (Figure 11b,c). In this case more than $60 \%$ of protein fluorescence is quenched when protein binding sites are saturated (cf. Figure 11). Very small changes in the excitation spectra suggest that the ligand is bound to the protein as a neutral species; but some irregularities in the difference spectra (Figure 11c) may indicate that the binding sites in the hexameric PNP molecule are not equivalent, but this conclusion needs verification.

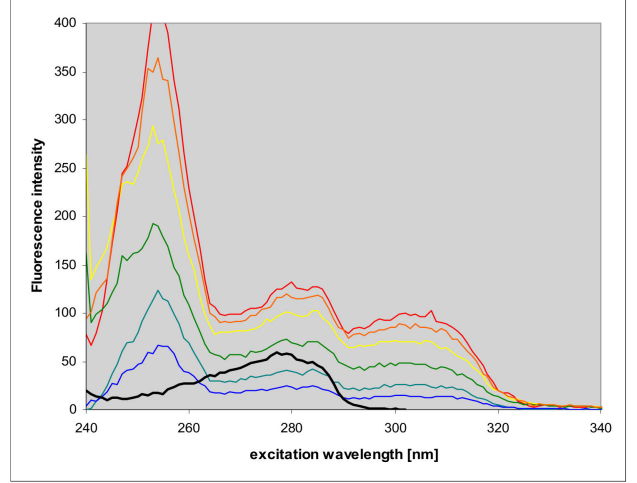

(a)

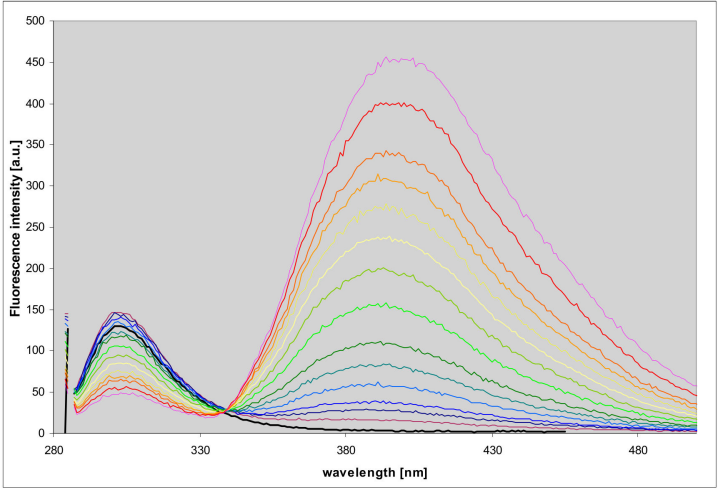

(b)

Figure 11. Cont. 


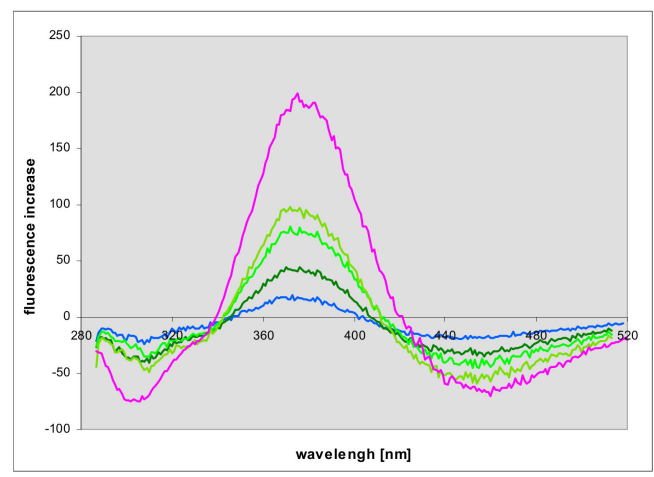

(c)

Figure 11. Changes in fluorescence excitation (a) and emission spectra (b), observed during the titration of E. coli PNP with 1, $\mathrm{N}^{6}$-etheno-tubercidine (6). Emission spectra were recorded with excitation at $280 \mathrm{~nm}$, excitation spectra were observed at $380 \mathrm{~nm}$. Conditions: $40 \mathrm{mM}$ phosphate buffer, $\mathrm{pH} 7$, at $20^{\circ} \mathrm{C}$. The concentration of protein was $11 \mu \mathrm{M}$ per subunit; that of $1, \mathrm{~N}^{6}$-etheno-tubercidine was $(0-18.5 \mu \mathrm{M})$. Black curves refer to pure protein emission or excitation (observed at $310 \mathrm{~nm}$ ); (c) fluorescence difference spectra of $11 \mu \mathrm{M}$ E. coli PNP, titrated with 1, $\mathrm{N}^{6}$-etheno-tubercidine $(1.9,3.7,5.4,7.1$ and $18.5 \mu \mathrm{M})$, calculated from data in panel $(\mathbf{b})$.

\section{Discussion}

\subsection{Fluorescent Isomers of the Etheno-2-Aminopurine}

Vinyl chloride, a known chemical mutagen and carcinogen, acts as a modifier of nucleobases, in particular, of adenine and guanine moieties [14,15], which upon this chemical modification change the respective coding properties, leading to the mutagenic effect [33,34]. In addition some of the bases modified in this way exhibit additionally marked fluorescence [1-4], which make them good candidates for fluorescent probes in enzymological research.

We found two isomeric products of the reaction of CAA with 2-aminopurine, both revealing intense fluorescence in aqueous medium. In both cases, fluorescence was excitation-dependent and decays were non-exponential. The most likely interpretation of this fact is the $\mathrm{N}^{9} \mathrm{H}-\mathrm{N}^{7} \mathrm{H}$ tautomerism, confirmed for some purines and analogs [35-37], and suggested for 1, $\mathrm{N}^{6}$-ethenoadenine [21], but other tautomeric forms, like $\mathrm{N}^{2} \mathrm{H}$ or $\mathrm{N}^{3} \mathrm{H}$, cannot be excluded (see Figure 12). The similarity between properties of the minor tautomers and $\mathrm{N}^{2}$-ribosides strongly suggests participation of the $\mathrm{N}^{2} \mathrm{H}$ protomers 1d, 2c.<smiles>c1cn2cc3nc[nH]c3nc2n1</smiles>

(1a)<smiles>c1nc2cn3ccnc3[nH]c-2n1</smiles>

(1c)<smiles>c1cn2cc3[nH]cnc3nc2n1</smiles>

(1b)<smiles>c1nc2cn3cc[nH]c3nc-2n1</smiles>

(1d)<smiles>c1cn2c(n1)ncc1nc[nH]c12</smiles>

(2a)<smiles>C1=CN2c3nc[nH]c3C=NC2N1</smiles>

(2c)<smiles>c1cn2c(n1)ncc1[nH]cnc12</smiles>

(2b)<smiles></smiles>

(2d)

Figure 12. Possible tautomeric structures of two isomers of etheno-2-aminopurine: $1, \mathrm{~N}^{2}$-etheno-2aminopurine (1a-d), $\mathrm{N}^{2}, 3$-etheno-2-aminopurine (2a-d). 
Large Stokes' shifts observed for the cationic species of both isomers suggests photo-transformations. Such photo-transformations (e.g., excited-state proton transfer and a resulting photo-tautomerism) are not infrequent among the fluorescent purine analogs and derivatives [38].

\subsection{Enzymatic Syntheses of the Tri-Cyclic Ribosides and Their Properties}

In this and preceding papers [21,22], we have described substrate and inhibitor properties of several tri-cyclic nucleobase analogs towards the enzyme purine-nucleoside phosphorylase. Many of the investigated compounds, in particular, etheno-adenosine and one isomer of etheno-guanosine were found to be excellent substrates for the bacterial (E. coli) type of PNP, and the respective bases were easily ribosylated in the reverse process [21,22]. Enzymatic ribosylation of the tri-cyclic nucleobase analogs and similar compounds leads to non-typical ribosides, which are nevertheless good substrates for $\mathrm{PNP}$, as shown previously for the $\mathrm{N}^{6}$-ribosylated $1, \mathrm{~N}^{6}$-ethenoadenine [21], and analogous isoguanine derivatives [22].

Both isomers of etheno-2-aminopurine ( $\mathbf{1}$ and 2 ) are ribosylated using R1P as a ribose donor and the E. coli PNP as a catalyst, but the ribosylation site is $\mathrm{N}^{2}$, rather than $\mathrm{N}^{9}$. Somewhat similar ribosylation pattern was previously reported for etheno-adenine [21] and etheno-isoguanine [22], but in both cases different enzyme forms led to different ribosylation products. By contrast, the linear isomer of etheno-guanine was rapidly ribosylated on the "canonical" $\mathrm{N}^{9}$ nitrogen [22].

This ambiguity in the ribosylation sites in enzymatic reactions, catalyzed by PNP, was also previously observed in 8-azapurines $[39,40]$, and probably results from the plasticity of the active site of this class of enzymes. For example, in the X-ray crystal structure of hexameric PNP from $H$. pylori, bound to an inhibitor formycin A (8-aza- $\mathrm{N}^{9}$-deazaadenosine), both the standard (anti) and non-standard (syn) conformations of the inhibitor were revealed [41]. In another study, acyclo-guanosine, an inhibitor of mammalian PNPs, with the acyclic chain bound to $\mathrm{N}^{7}$ position of the purine base, was found in the inverted ('up-side-down') position in the active site of calf PNP, with the chain located in the place normally occupied by the ribose [42]. Finally, $\mathrm{N}^{3}-\beta$-D-ribofuranosyladenine and $\mathrm{N}^{3}$ - $\beta$-D-ribofuranosyl-hypoxanthine, with sugar moiety attached to the $\mathrm{N}_{3}$ position of the base, were found to be non-conventional substrates of purine nucleoside phosphorylase from E. coli and calf [43].

Some of the fluorescent tri-cyclic ribosides are also moderate to good substrates of mammalian PNPs, known to be homologous to human enzymes [12]. This makes them potential indicators of PNP activity in biological or clinical samples. As an illustration, we have recently shown that human erythrocytic PNP activity can be measured fluorimetrically in 1000-fold diluted hemolysates using the $\mathrm{N}^{6}$-ribosylated 1, $\mathrm{N}^{6}$-ethenoadenine as an artificial substrate [44]. We expect that the new compounds presented in this work, particularly the ribosides of $\mathrm{N}^{2}, 3$-etheno-2-aminopurine (2), will exceed in sensitivity other fluorescent indicators of PNP activity (to be published elsewhere).

\subsection{Fluorescent Complexes}

Various forms of PNP form fluorescent complexes with purines and their analogs [17]. Long ago Porter et al. [45] reported a fluorescent complex of calf PNP with guanine, ascribing its fluorescence to the anionic form of the ligand. Later investigations with fluorescent 8-azaguanine derivatives and calf PNP $[46,47]$ instead suggested neutral ligand as the emission source. The E. coli PNP is an interesting object of this kind of experiments since its molecule does not contain tryptophan and its native fluorescence is located near $305 \mathrm{~nm}$ [12], allowing easy observations of emission of the complexes, as illustrated by Kierdaszuk et al. [31,32]. In the latter case, it was possible to identify individual protomeric forms of the ligand formycin A (8-aza- $\mathrm{N}^{9}$-deazaadenosine), when bound to the PNP molecule.

Somewhat similar fluorescent complexes and FRET were previously observed with E. coli PNP complexed with formycin A and its $\mathrm{N}$-methyl derivatives as ligands [31]. Now, we present evidence for the highly fluorescent base-enzyme complexes, observed in the presence of phosphate. We did not observe analogous complexes in the absence of phosphate, in spite of the low Michaelis' constants 
obtained for the synthetic reaction (Table 3). This is in line with the fact that for both mammalian and bacterial PNPs, due to complex mechanisms of catalysis exhibited by these two enzyme families, $\mathrm{K}_{\mathrm{m}}$ does not describe the affinity of most substrates, e.g., [12,16,48] adequately. This also suggests that, in agreement with previous mechanistic considerations and stabilization pattern exhibited by substrates [49], the purine base is the only E. coli PNP substrate that cannot bind to the enzyme molecule in the absence of either a second substrate (in this case R1P) in the synthetic reaction, or phosphate, a substrate in the reverse phosphorolytic path, in the latter case forming a so-called dead-end complex.

Previous papers have shown that the E. coli PNP molecule can selectively bind individual tautomeric forms of some ligands [31,32]. At present, we cannot identify which of possible tautomeric structures is bound, but the minor tautomer, visible in solution spectra as an inflection, and postulated to be the $\mathrm{N}^{2} \mathrm{H}$ protomer $\mathbf{2 c}$, is evidently not responsible for the above changes since the emission spectra of the complex differ markedly from those of the $\mathrm{N}^{2}$-riboside 5 (cf. Figures 10 and 5). Our interpretation of the presented data is that $\mathrm{N}^{7}$ or $\mathrm{N}^{9}$ are likely locations of the proton in the complex.

\section{Materials and Methods}

\subsection{Chemicals}

2-Aminopurine (2AP), chloroacetaldehyde (CAA) and 7-methylguanosine ( $\left.\mathrm{m}^{7} \mathrm{Guo}\right)$ were from Sigma-Aldrich (St. Louis, MO, USA). Tubercidine (7-deazaadenosine) was a gift from Dr. Janusz Stępiński from the University of Warsaw (Warsaw, Poland). 2-Aminopurine- $\mathrm{N}^{9}-\beta$-D-riboside was from Santa Cruz Biotechnology (Dallas, Texas, USA).

The ribose source for enzymatic ribosylation, $\alpha$-D-ribose-1-phosphate (R1P) has been prepared enzymatically as a $100 \mathrm{mM}$ solution from 7-methylguanosine phosphorolysed by calf PNP, as previously described $[33,50]$ and kept frozen.

Etheno-derivatives of 2-aminopurine ( $22 \mathrm{AP})$ were obtained as follows: 2-aminopurine (2AP, $1 \mathrm{~g}$, 7.4 mmoles) was dissolved in $30 \mathrm{~mL}$ of $\sim 0.1 \mathrm{M}$ acetic acid. After adjusting $\mathrm{pH}$ to $\sim 4$ by sodium bicarbonate, the mixture was treated with $0.5 \mathrm{~mL} \mathrm{CAA} \mathrm{(50 \%} \mathrm{aqueous} \mathrm{solution),} \mathrm{for} \mathrm{ca.} 24 \mathrm{~h}$ at room temperature, and warming at the end to $\sim 40{ }^{\circ} \mathrm{C}$ for ca. $30 \mathrm{~min}$. HPLC analysis showed the disappearance of $>90 \%$ 2AP. The solution was neutralized by sodium bicarbonate and left in a refrigerator for 24 hours. The major product, identified as $1, \mathrm{~N}^{2}$-etheno-2-aminopurine $\left(1, \mathrm{~N}^{2}-\varepsilon 2 \mathrm{AP}\right.$, (1)), crystallized in the form of plates ( $400 \mathrm{mg}, 2.5 \mathrm{mmoles}$, slowly darkening in the air; overall yield $\sim 35 \%$ ). The mother liquors were subjected to semi-preparative HPLC to give ca. $50 \mathrm{mg} \mathrm{(5 \% )} \mathrm{of} \mathrm{an}$ additional, minor but highly fluorescent product, identified as $\mathrm{N}^{2}, 3$-etheno-2-aminopurine $\left(\mathrm{N}^{2}, 3-\varepsilon 2 \mathrm{AP}\right.$ (2)). This product was concentrated and kept frozen. MS: comp. 1: $\mathrm{m} / \mathrm{z}=160.0617$, comp. $2: \mathrm{m} / \mathrm{z}=160$. 0619; calculated for $\mathrm{C}_{7} \mathrm{H}_{5} \mathrm{~N}_{5}+\mathrm{H}$ : 160.0612 .

The etheno-derivative of 2-aminopurine- $\mathrm{N}^{9}-\beta$-D-riboside (Figure 13) was prepared according to Virta et al. [23], and crystallized from the neutralized reaction mixture. Its structure was confirmed by NMR data, which were in agreement with the published results [23], and by MS: comp. 3: $\mathrm{m} / \mathrm{z}=292.10385$, calculated for $\mathrm{C}_{12} \mathrm{H}_{13} \mathrm{~N}_{5} \mathrm{O}_{4}+\mathrm{H}: 292.10403$. 
<smiles>Nc1ncc2nc[nH]c2n1</smiles>

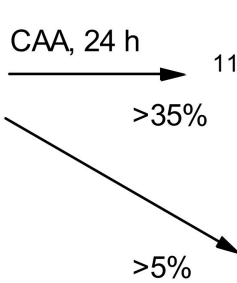

$>5 \%$<smiles></smiles>

(2)

(1)

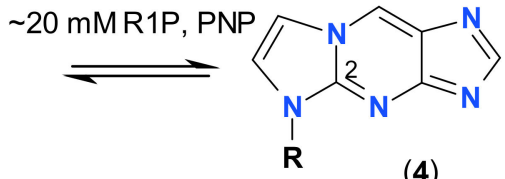

(4)

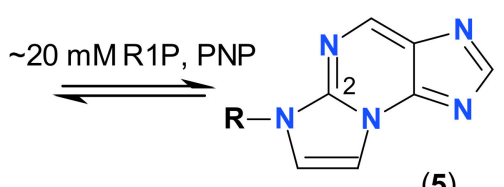

(5)<smiles>[R]n1cnc2cnc(N)nc21</smiles><smiles>[R2]n1cnc2cn3ccnc3nc21</smiles>

(3)

Figure 13. Synthesis of 2-aminopurine etheno-derivatives and their ribosides ( $\mathrm{R}=\beta$-D-ribofuranosyl; $\mathrm{CAA}=$ chloroacetaldehyde, $\mathrm{R} 1 \mathrm{P}-\alpha$-D-ribose-1-phosphate; PNP = purine-nucleoside phosphorylase).

The reaction of chloroacetaldehyde with tubercidine (7-deazaadenosine) was carried out as previously described [24], with the modification that an aqueous CAA was applied instead of the distilled reactant. The product purified by semi-preparative HPLC in milligram quantities (approximate yield $>60 \%$ ). The spectral parameters were in agreement with those previously published [24]. See Supplementary Materials for more details.

Product separation and purification were performed by HPLC on a UFLC system from Shimadzu (Kyoto, Japan) equipped with UV (diode-array) detection at 260, 280 and $315 \mathrm{~nm}$, and a fluorescence detector. The column used was a Kromasil reversed-phase, semi-preparative C-18 column $(250 \times 10 \mathrm{~mm}$, 5- $\mu \mathrm{m}$ particle size). Elution was initially (10-15 $\mathrm{min}$ ) isocratic, followed by a water-methanol gradient (usually 10-30\% methanol for $40 \mathrm{~min}$, see Supplementary Materials for details). All buffers were of analytical grade and showed no fluorescence background.

\subsection{Spectral Measurements}

Fluorescence spectra were measured on a Varian Eclipse instrument (Varian Corp., Palo Alto, CA, USA), and UV absorption kinetic experiments were performed on a Cary 5000 (Varian Corp., Palo Alto, CA, USA) thermostated spectrophotometer. Fluorescence yields were determined relative to tryptophan (0.15) or $1, \mathrm{~N}^{6}$-ethenoadenosine in water (0.56, see ref. [2]). Emission spectra were measured in semi-micro cuvettes, pathlength $4 \mathrm{~mm}$, to diminish the inner-filter effect. Typical spectral resolution was $2.5 \mathrm{~nm}$. The ionization constants $\left(\mathrm{pK}_{\mathrm{a}}\right.$ values) were determined spectrophotometrically using 20-50 mM phosphate and/or acetate buffers.

Fluorescence decays were measured and analyzed using a FluoTime 200 lifetime fluorometer (PicoQuant GmbH, Berlin, Germany), equipped with an R3809U-50 microchannel-plate photo-multiplier (MCP-PMT, Hamamatsu, Japan), with $280 \mathrm{~nm}$ excitation by sub-nanosecond pulsed LED, as previously described [50].

NMR measurements were run in DMSO- $\mathrm{d}_{6}$ at $25^{\circ} \mathrm{C}$ on an Avance III HD $800 \mathrm{MHz}$ spectrometer Bruker (Bruker BioSpin AG, Fällanden, Switzerland) equipped with a cryogenically-cooled triple resonance $(\mathrm{HCN})$ probe (the sample identified as the $\mathrm{N}^{2}$-riboside of $1, \mathrm{~N}^{2}$-etheno-2-aminopurine (3)) and on a Bruker Avance III HD $500 \mathrm{MHz}$ spectrometer equipped with a room-temperature triple resonance $(\mathrm{HCN})$ probe. For all samples, the following spectra were acquired: a standard $1 \mathrm{D}$ proton spectrum, a ${ }^{1} \mathrm{H},{ }^{1} \mathrm{H}$ CLIP-COSY [51] and a gradient-selected ${ }^{1} \mathrm{H},{ }^{13} \mathrm{C}$ HSQC [52]. Phase-sensitive gradient-selected HMBC spectra tuned for 2 and $8 \mathrm{~Hz} \mathrm{~J}$ couplings were acquired for the $\mathrm{N}^{2}$ riboside of 1, $\mathrm{N}^{2}$-etheno-2-aminopurine (3), while gradient-selected ${ }^{1} \mathrm{H},{ }^{13} \mathrm{C}$ HSQMBC ([53], modified by using 
hard pulses) were run for all other samples-tuned for optimal detection of $12 \mathrm{~Hz} \mathrm{~J}$ couplings in the case of $1, \mathrm{~N}^{2}$-etheno-2-aminopurine or two separate experiments tuned for $2 \mathrm{~Hz}$ and $8 \mathrm{~Hz} \mathrm{~J}$ couplings otherwise. ${ }^{1} \mathrm{H}$ chemical shifts were referenced by the field-locked substitution method using a (less than) $1 \%$ sample of TMS in DMSO- $\mathrm{d}_{6}$, and ${ }^{13} \mathrm{C}$ chemical shifts were referenced using the unified chemical shift scale [54]. The 2D spectra were processed using the TopSpin 3.6.1 software package (Bruker) and inspected by the Sparky program [55] with manual peak-picking.

\subsection{Mass Spectrometry}

The structure and purity of the new compounds 1-2 and 4-5 were confirmed using the high-resolution mass spectrometry with positive electrospray ionization HRMS (+) ESI. Mass spectra were recorded on a Thermo Scientific QExactive spectrometer (Thermo Fisher Scientific, Waltham, MA, USA). Spray voltage was $3800 \mathrm{~V}$, capillary temperature $320^{\circ} \mathrm{C}$.

\subsection{Enzymes and Enzymatic Reactions}

Recombinant E. coli PNP, calf spleen PNP, and their mutated forms were expressed in E. coli and purified according to the procedures described earlier [56,57]. Enzyme concentrations were calculated per monomer.

Enzymatic ribosylation reactions were carried out in $1 \mathrm{~mL}$ cuvettes (pathlength $4 \mathrm{~mm}$ ) in $\sim 50 \mathrm{mM}$ HEPES buffer, $\mathrm{pH} 7.3$, using $0.5 \mathrm{mM} \mathrm{R1P}$ as a ribose source. Reactions were followed fluorimetrically (see Section 2.4). On a larger scale (2-4 mg), the reactions were run in Eppendorf tubes, volume 2-3 mL, using either R1P (3-10 mM) or 7-methylguanosine as ribose sources. Products were purified by semi-preparative HPLC, concentrated and the final solutions kept frozen. Their structure has been confirmed by NMR (see Section 2.4 and Supplementary Materials) and by MS: comp. 3: $\mathrm{m} / \mathrm{z}=292.10385$, comp. 4: $m / z=292.10400$, comp. 5: $m / z=292.10398$, calculated for $\mathrm{C}_{12} \mathrm{H}_{13} \mathrm{~N}_{5} \mathrm{O}_{4}+\mathrm{H}: 292.10403$. Phosphorolysis reactions were run in 40-50 mM phosphate buffer, $\mathrm{pH} 7.0$ or 6.5, and followed spectrally or fluorimetrically. Kinetic parameters were calculated by standard methods.

\section{Conclusions}

We have shown that 2-aminopurine easily reacts with aqueous chloroacetaldehyde to give two fluorescent, isomeric products $\mathbf{1}$ and $\mathbf{2}$. Both products are substrates for the bacterial (E. coli) purine nucleoside phosphorylase, but in both cases the ribosylation site has been found to be $\mathrm{N}^{2}$ rather than $\mathrm{N}^{9}$. The new ribosides are fluorescent and potentially useful as fluorescent probes. The antibiotic tubercidine (7-deazaadenosine) also reacts with aqueous chloroacetaldehyde to give the fluorescent product 6. This product is an inhibitor of the E. coli PNP and forms fluorescent complexes with the enzyme.

Supplementary Materials: The Supplementary Materials are available online.

Author Contributions: Conceptualization, A.S.-W. and J.W.; methodology, J.W. (fluorescence), R.S. and M.G. (NMR measurements), B.W.-K. (life time measurements), A.S.-W. and J.W. (kinetic and spectroscopic measurements), A.S.-W. (HPLC analysis), B.W.-K. (enzyme cloning and purifications); investigation, all authors; resources (preparation work), A.B. and B.W.-K.; writing-original draft preparation, J.W. and A.S.-W.; writing-review and editing, A.B. and B.W.-K.; supervision, R.S. and A.B.; funding acquisition, A.S.-W., A.B., R.S. and B.W.-K. All authors have read and agreed to the published version of the manuscript.

Funding: This work profited from the "MINIATURA" grant \#DEC-2017/01/X/ST5/00807 from National Center of Sciences (NCN, Cracow, Poland), project 17.610.011-110 from the University of Warmia and Mazury in Olsztyn, and projects BST-185500/BF, 501-D111-01-1110102-PP/BF, and 500-D111-12-1110100 from the Polish Ministry of Science and Higher Education. Publication was co-financed by the University of Warsaw.

Acknowledgments: We thank Janusz Stepiński (University of Warsaw) for a gift of tubercidine, and Michał Dadlez and J. Oledzki (the Institute of Biochemistry and Biophysics, Polish Academy of Sciences, both) for HRMS measurements.

Conflicts of Interest: The authors declare no conflict of interest. 


\section{References}

1. Leonard, N.J. Adenylates: Bound and unbound. Biopolymers 1985, 24, 9-28. [CrossRef]

2. Leonard, N.J. Etheno-substituted nucleotides and coenzymes: Fluorescence and biological activity. Crit. Rev. Biochem. 1984, 15, 125-199. [CrossRef] [PubMed]

3. Sinkeldam, R.W.; Greco, N.J.; Tor, Y. Fluorescent analogs of biomolecular building blocks: Design, properties, and applications. Chem. Rev. 2010, 110, 2579-2619. [CrossRef] [PubMed]

4. Xu, W.; Chan, K.M.; Kool, E.T. Fluorescent nucleobases as tools for studying DNA and RNA. Nat. Chem. 2017, 9, 1043-1055. [CrossRef]

5. Kauffman, R.F.; Lardy, H.A.; Barrio, J.R.; Barrio, C.G.; Leonard, N.J. Dimensional probes of enzyme binding-sites of adenine-nucleotides-interaction of lin-benzo-adenosine 5 '-diphosphate and triphosphate with mitochondrial ATP-synthetase, purified ATPase, and adenine-nucleotide carrier. Biochemistry 1978, 17, 3686-3692. [CrossRef] [PubMed]

6. Scopes, D.I.C.; Barrio, J.R.; Leonard, N.J. Defined dimensional changes in enzyme cofactors-fluorescent stretched-out analogs of adenine-nucleotides. Science 1977, 195, 296-298. [CrossRef]

7. Golankiewicz, B.; Ostrowski, T. Tricyclic nucleoside analogues as antiherpes agents. Antivir Res. 2006, 71, 134-140.

8. Jahnz-Wechmann, Z.; Framski, G.R.; Januszczyk, P.A.; Boryski, J. Bioactive fused heterocycles: Nucleoside analogs with an additional ring. Eur. J. Med. Chem. 2015, 97, 388-396. [CrossRef]

9. Jahnz-Wechmann, Z.; Framski, G.R.; Januszczyk, P.A.; Boryski, J. Base-modified nucleosides: Etheno derivatives. Front. Chem. 2016, 4, 19-29. [CrossRef]

10. Singer, B.; Kuśmierek, J.T. Chemical mutagenesis. Annu. Rev. Biochem. 1982, 51, 655-693. [CrossRef]

11. Chatterjee, N.; Walker, G.C. Mechanisms of DNA damage, repair and mutagenesis. Env. Mol Mutagen. 2017, 58, 235-263. [CrossRef] [PubMed]

12. Bzowska, A.; Kulikowska, E.; Shugar, D. Purine nucleoside phosphorylases: Properties, functions, and clinical aspects. Pharmacol. Therap. 2000, 88, 349-425. [CrossRef]

13. El Kouni, M.H. Potential chemotherapeutic targets in the purine metabolism of parasites. Pharmacol. Ther. 2003, 99, 283-309. [CrossRef]

14. Grunebaum, E.; Cohen, A.; Roifman, C.M. Recent advances in understanding and managing adenosine deaminase and purine nucleoside phosphorylase deficiencies. Curr. Op. Allergy Clin. Immunol. 2013, 13, 630-638. [CrossRef]

15. Parker, W.B.; Sorscher, E.J. Use of E. coli purine nucleoside phosphorylase in the treatment of solid tumors. Curr. Pharm Des. 2017, 23, 7003-7024. [CrossRef]

16. Doskocil, J.; Holy, A. Specificity of purine nucleoside phosphorylase from Escherichia coli. Collect. Czech. Chem. Commun. 1977, 42, 370-383. [CrossRef]

17. Wierzchowski, J.; Stachelska-Wierzchowska, A.; Wielgus-Kutrowska, B.; Bzowska, A. 1, $\mathrm{N}^{6}$-ethenoadenine and other fluorescent nucleobase analogues as substrates for purine-nucleoside phosphorylases: Spectroscopic and kinetic studies. Curr. Pharm. Des. 2017, 23, 6972-6990.

18. Mikhailopulo, A.I.; Miroshnikov, A.I. Biologically important nucleosides: Modern trends in biotechnology and application. Mendeleev Comm. 2011, 21, 57-68. [CrossRef]

19. Kamel, S.; Yehia, H.; Neubauer, P.; Wagner, A. 1 Enzymatic Synthesis of Nucleoside Analogues by Nucleoside Phosphorylases 1. In Enzymatic and Chemical Synthesis of Nucleic Acid Derivatives; Fernandez-Lucas, J., Camarasa-Rius, M.J., Eds.; Wiley-VCH Verlag GmbH \& Co. KGaA: Weinheim, Germany, 2019; Chapter 1; pp. 1-28.

20. Yehia, H.; Kamel, S.; Paulick, K.; Neubauer, P.; Wagner, A. Substrate Spectra of Nucleoside Phosphorylases and their Potential in the Production of Pharmaceutically Active Compounds. Curr. Pharm. Des. 2017, 23, 6913-6935. [CrossRef]

21. Stachelska-Wierzchowska, A.; Wierzchowski, J.; Bzowska, A.; Wielgus-Kutrowska, B. Tricyclic nitrogen base, 1, $\mathrm{N}^{6}$-Ethenoadenine, and its Ribosides, as Substrates for Purine-Nucleoside Phosphorylases: Spectroscopic and Kinetic Studies. Nucleosides Nucleotides Nucleic Acids 2018, 37, 89-101. [CrossRef]

22. Stachelska-Wierzchowska, A.; Wierzchowski, J.; Wielgus-Kutrowska, B.; Bzowska, A. Tri-cyclic nucleobase analogs and their ribosides as substrates of purine-nucleoside phosphorylases. II. Guanine and isoguanine derivatives. Molecules 2019, 24, 1493. [CrossRef] [PubMed] 
23. Virta, P.; Holmstrom, T.; Roslund, M.U.; Mattjus, P.; Kronberg, L.; Sjoholm, R. New nucleoside analogs from 2-amino-9-( $\beta$-D-ribofuranosyl)purine. Org. Biomol. Chem. 2004, 2, 821-827. [CrossRef] [PubMed]

24. Bhat, G.A.; Schram, K.H.; Townsend, L.B. The synthesis of certain fluorescent imidazo[1,2-c]pyrrolo [3,2-e]pyrimidine nucleoside derivatives related to epsilon-adenosine. J. Carbohydr. Nucleosides Nucleotides 1980, 7, 333-345.

25. Seela, F.; Schweinberger, E.; Kuiying, X.; Sirivolu, V.R.; Rosemeyer, H.; Becker, E.-M. $1, \mathrm{~N}^{6}$-Etheno-2'-deoxytubercidin and pyrrolo-C: Synthesis, base pairing, and fluorescence properties of 7-deazapurine nucleosides and oligonucleotides. Tetrahedron 2007, 63, 3471-3482. [CrossRef]

26. Evans, G.B.; Schramm, V.L.; Tyler, P.C. The Immucillins: Design, synthesis and application of transition-state analogues. Curr. Med. Chem. 2015, 22, 3897-3909. [CrossRef]

27. Schramm, V.L. Transition states, analogues, and drug development. Acs Chem. Biol. 2013, 8, 71-81.

28. Markley, J.L.; Bax, A.; Arata, Y.; Hilbers, C.W.; Kaptein, R.; Sykes, B.D.; Wright, P.E.; Wüthrich, K. Recommendations for the presentation of NMR structures of proteins and nucleic acids-IUPAC-IUBMB-IUPAB Inter-Union Task Group on the standardization of data bases of protein and nucleic acid structures determined by NMR spectroscopy. J. Biomol. Nmr 1998, 12, 1-23. [CrossRef]

29. Stoeckler, J.D.; Poirot, A.F.; Smith, R.M.; Parks, R.E., Jr.; Ealick, S.E.; Takabayashi, K.; Erion, M.D. Purine nucleoside phosphorylase. 3. Reversal of purine base specificity by site-directed mutagenesis. Biochemistry 1997, 36, 11749-11756. [CrossRef]

30. Kamel, S.; Thiele, I.; Neubauer, P.; Wagner, A. Thermophilic nucleoside phosphorylases: Their properties, characteristics and applications. Biochim. Biopys. Acta-Proteins Proteom. 2020, 1868, 140304. [CrossRef]

31. Kierdaszuk, B.; Modrak-Wójcik, A.; Wierzchowski, J.; Shugar, D. Formycin A and its N-methyl analogues, specific inhibitors of $E$. coli purine nucleoside phosphorylase: Induced tautomeric shift on binding to enzyme, and enzyme $\rightarrow$ ligand fluorescence resonance energy transfer. Biochim. Biophys. Acta 2000, 1476, 109-128. [CrossRef]

32. Włodarczyk, J.; Galitonov, G.S.; Kierdaszuk, B. Identification of the tautomeric form of formycin A in its complex with Escherichia coli purine nucleoside phosphorylase based on the effect of enzyme-ligand binding on fluorescence and phosphorescence. Eur. Biophys. J. Biophys. Lett. 2004, 33, 377-385. [CrossRef]

33. Patra, A.; Su, Y.; Zhang, Q.Q.; Johnson, K.M.; Guengerich, F.P.; Egli, M. Structural and Kinetic Analysis of Miscoding Opposite the DNA Adduct 1, $\mathrm{N}^{6}$-Ethenodeoxyadenosine by Human Translesion DNA Polymerase. J. Biol. Chem. 2016, 291, 14134-14145. [CrossRef]

34. Calabretta, A.; Leumann, C.J. Base pairing and miscoding properties of $1, \mathrm{~N}^{6}$-ethenoadenine- and 3,N4 $\mathrm{N}^{4}$-ethenocytosine-containing RNA oligonucleotides. Biochemistry 2013, 52, 1990-1997. [CrossRef]

35. Shugar, D.; Psoda, A. Tautomerism of purines and pyrimidines. In Landoldt-Bornstein Numerical Data and Functional Relationships in Science and Technology; Springer: Berlin/Heidelberg, Germany, 1990; Volume 1, pp. 308-344.

36. Shcherbakova, I.; Elguero, J.; Katritzky, A.R. Tautomerism of heterocycles: Condensed five-six, five-five, and six-six ring systems with heteroatoms in both rings. Adv. Heterocycl. Chem. 2000, 77, 51-113.

37. Wierzchowski, J.; Antosiewicz, J.M.; Shugar, D. 8-Azapurines as isosteric purine fluorescent probes for nucleic acid and enzymatic research. Mol. Biosyst. 2014, 10, 2756-2774. [CrossRef]

38. Wierzchowski, J. Excited-state proton transfer and phototautomerism in nucleobase and nucleoside analogs: A mini-review. Nucleosides Nucleotides Nucleic Acids 2014, 33, 626-644. [CrossRef]

39. Stachelska-Wierzchowska, A.; Wierzchowski, J.; Wielgus-Kutrowska, B.; Bzowska, A.; Mikleuševic, G. Enzymatic synthesis of highly fluorescent 8-azapurine ribosides using purine-nucleoside phosphorylase reverse reaction: Variable ribosylation sites. Molecules 2013, 18, 12587-12598. [CrossRef]

40. Stachelska-Wierzchowska, A.; Wierzchowski, J.; Bzowska, A.; Wielgus-Kutrowska, B. Site-selective ribosylation of fluorescent nucleobase analogs using purine-nucleoside phosphorylase as a catalyst: Effects of point mutations. Molecules 2016, 21, 44. [CrossRef]

41. Narczyk, M.; Bertoša, B.; Papa, L.; Vuković, V.; Leščić-Ašler, I.; Wielgus-Kutrowska, B.; Bzowska, A.; Luić, M.; Štefanić, Z. Helicobacter pylori purine nucleoside phosphorylase shows new distribution patterns of open and closed active site conformations and unusual biochemical features. FEBS J. 2018, 285, 1305-1325. [CrossRef]

42. Bzowska, A.; Luić, M.; Schroder, W.; Shugar, D.; Saenger, W.; Koellner, G. Calf spleen purine nucleoside phosphorylase: Purification, sequence and crystal structure of its complex with N(7)-acycloguanosine inhibitor. FEBS Lett. 1995, 367, 214-218. [CrossRef] 
43. Bzowska, A.; Kulikowska, E.; Poopeiko, N.E.; Shugar, D. Kinetics of phosphorolysis of 3-( $\beta$-D-ribofuranosyl)adenine and 3-( $\beta$-D-ribofuranosyl)hypoxanthine, non-conventional substrates of purine-nucleoside phosphorylase. Eur. J. Biochem. 1996, 239, 229-234. [CrossRef] [PubMed]

44. Stachelska-Wierzchowska, A.; Wierzchowski, J. Fluorescence of the tri-cyclic adenine and isoguanine derivatives and their ribosides: Possible analytical applications. Acta Biochim. Polon. 2019, 66, 2885. [CrossRef] [PubMed]

45. Porter, D.J.T. Purine nucleoside phosphorylase-kinetic mechanism of the enzyme from calf spleen. J. Biol. Chem. 1992, 267, 7342-7351. [PubMed]

46. Wierzchowski, J.; Bzowska, A.; Stępniak, K.; Shugar, D. Interactions of Calf Spleen Purine Nucleoside Phosphorylase with 8-Azaguanine, and a Bisubstrate Analogue Inhibitor: Implications for the Reaction Mechanism. Z Nat. C J Biosci. 2004, 59, 713-725. [CrossRef]

47. Wierzchowski, J.; Stępniak, K.; Bzowska, A.; Shugar, D. Spectroscopic and kinetic studies of interactions of calf spleen purine nucleoside phosphorylase with 8-azaguanine and its 9-(2-phosphonylmethoxyethyl) derivative. Nucleosides Nucleotides Nucleic Acids 2005, 24, 459-464. [CrossRef]

48. Bzowska, A. Calf spleen purine nucleoside phosphorylase: Complex kinetic mechanism, hydrolysis of 7-methylguanosine, and oligomeric state in solution. Biochim. Biopys. Acta 2002, 1596, 293-317. [CrossRef]

49. Krentitsky, T.A.; Tuttle, J.V. Correlation of substrate stabilization patterns with proposed mechanisms for three nucleoside phosphorylases. Biochim. Biophys. Acta 1982, 703, 247-249. [CrossRef]

50. Wierzchowski, J.; Mędza, G.; Szabelski, M.; Stachelska-Wierzchowska, A. Properties of 2,6-diamino-8-azapurine, a highly fluorescent purine analog and its $\mathrm{N}$-alkyl derivatives: Tautomerism and excited-state proton transfer reactions. J. Photochem. Photobiol. A 2013, 265, 49-57. [CrossRef]

51. Koos, M.R.M.; Kummerlöwe, G.; Kaltschnee, L.; Thiele, C.M.; Luy, B. CLIP-COSY: A Clean In-Phase Experiment for the Rapid Acquisition of COSY-type Correlations. Angew. Chem. Internat. Ed. 2016, 55, 7655-7659. [CrossRef]

52. Davis, A.L.; Keeler, J.; Laue, E.D.; Moskau, D. Experiments for recording pure-absorption heteronuclear correlation spectra using pulsed field gradients. J. Magn. Reson. 1992, 98, 207-216. [CrossRef]

53. Saurí, J.; Parella, T.; Espinosa, J.F. CLIP-HSQMBC: Easy measurement of small proton-carbon coupling constants in organic molecules. Org. Biomol. Chem. 2013, 11, 4473. [CrossRef] [PubMed]

54. Harris, R.K.; Becker, E.D.; De Menezes, S.M.C.; Granger, P.; Hoffman, R.E.; Zilm, K.W. Further conventions for NMR shielding and chemical shifts (IUPAC Recommendations 2008). Pure Appl. Chem. 2008, 80, 59-84. [CrossRef]

55. Goddard, T.D.; Kneller, D.G. SPARKY 3; University of California: San Francisco, CA, USA, 2000.

56. Mikleuševic, G.; Štefanic, Z.; Narczyk, M.; Wielgus-Kutrowska, B.; Bzowska, A.; Luic, M. Validation of the catalytic mechanism of Escherichia coli purine nucleoside phosphorylase by structural and kinetic studies. Biochimie 2011, 93, 1610-1622. [CrossRef] [PubMed]

57. Breer, K.; Girstun, A.; Wielgus-Kutrowska, B.; Staron, K.; Bzowska, A. Overexpression, purification and characterization of functional calf purine nucleoside phosphorylase (PNP). Protein Expr. Purif. 2008, 61, 122-130. [CrossRef]

Sample Availability: Samples of the compounds 1, $\mathrm{N}^{2}$-etheno-2-aminopurine (1), $\mathrm{N}^{2}, 3$-etheno-2-aminopurine (2) are available from the authors.

(C) 2020 by the authors. Licensee MDPI, Basel, Switzerland. This article is an open access article distributed under the terms and conditions of the Creative Commons Attribution (CC BY) license (http://creativecommons.org/licenses/by/4.0/). 